\title{
Do Institutions Cause Growth?
}

\section{Citation}

Glaeser, Edward L., Rafael La Porta, Florencio Lopez-de-Silanes, and Andrei Shleifer. 2004. “Do Institutions Cause Growth?" Journal of Economic Growth 9 (3) (September): 271-303. doi:10.1023/b:joeg.0000038933.16398.ed.

\section{Published Version}

doi:10.1023/B:JOEG.0000038933.16398.ed

\section{Permanent link}

http://nrs.harvard.edu/urn-3:HUL.InstRepos:27867242

\section{Terms of Use}

This article was downloaded from Harvard University's DASH repository, and is made available under the terms and conditions applicable to Other Posted Material, as set forth at http:// nrs.harvard.edu/urn-3:HUL.InstRepos:dash.current.terms-of-use\#LAA

\section{Share Your Story}

The Harvard community has made this article openly available.

Please share how this access benefits you. Submit a story.

Accessibility 
NBER WORKING PAPER SERIES

DO INSTITUTIONS CAUSE GROWTH?

Edward L. Glaeser

Rafael La Porta

Florencio Lopez-de-Silanes

Andrei Shleifer

Working Paper 10568

http://www.nber.org/papers/w10568

\author{
NATIONAL BUREAU OF ECONOMIC RESEARCH \\ 1050 Massachusetts Avenue \\ Cambridge, MA 02138 \\ June 2004
}

We thank Philippe Aghion, Olivier Blanchard, Oded Galor, Simon Johnson, Aart Kraay, Ross Levine, Torsten Persson, Dani Rodrik and an anonymous referee for helpful comments, and Sebastian Brown for research assistance. The views expressed herein are those of the author(s) and not necessarily those of the National Bureau of Economic Research.

(C2004 by Edward L. Glaeser, Rafael La Porta, Florencio Lopez-de-Silanes, and Andrei Shleifer. All rights reserved. Short sections of text, not to exceed two paragraphs, may be quoted without explicit permission provided that full credit, including (C) notice, is given to the source. 
Do Institutions Cause Growth?

Edward L. Glaeser, Rafael La Porta, Florencio Lopez-de-Silanes, and Andrei Shleifer NBER Working Paper No. 10568

June 2004

JEL No. O11, O40

\section{$\underline{\text { ABSTRACT }}$}

We revisit the debate over whether political institutions cause economic growth, or whether, alternatively, growth and human capital accumulation lead to institutional improvement. We find that most indicators of institutional quality used to establish the proposition that institutions cause growth are constructed to be conceptually unsuitable for that purpose. We also find that some of the instrumental variable techniques used in the literature are flawed. Basic OLS results, as well as a variety of additional evidence, suggest that a) human capital is a more basic source of growth than are the institutions, b) poor countries get out of poverty through good policies, often pursued by dictators, and c) subsequently improve their political institutions.

Edward L. Glaeser

Department of Economics

Harvard University

315A Littauer Center

Cambridge, MA 02138

and NBER

eglaeser@harvard.edu

Rafael La Porta

Tuck School of Business

Dartmouth College

314 Woodbury

Hanover, NH 03755

and NBER

rafael.laporta@dartmouth.edu

Florencio Lopez-de-Silanes

Yale School of Management

135 Prospect Street

P.O. Box 208200

New Haven, CT 06517

and NBER

florencio.lopezdesilanes@yale.edu

Andrei Shleifer

Department of Economics
Harvard University

M9 Littauer Center

Cambridge, MA 02138

and NBER

ashleifer@harvard.edu 


\section{Introduction.}

Today, both the U.S. and the international community face two major development challenges around the world, from Iraq, to Haiti, to sub-Saharan Africa: how to ignite growth and how to establish democracy. Economic research has identified two broad approaches to confronting these challenges. The first approach emphasizes the need to start with democracy and other checks on government as the mechanisms for securing property rights. With such political institutions in place, investment in human and physical capital, and therefore economic growth, are expected to follow. The second approach emphasizes the need for human and physical capital accumulation to start the process. It holds that even pro-market dictators can secure property rights as a matter of policy choice, not of political constraints. From the vantage point of poor countries, it sees democracy and other institutional improvements as the consequences of increased education and wealth, not as their causes.

Both approaches to development have extensive intellectual pedigree. The importance of constraining government was stressed by Montesquieu (1748) and Smith (1776), as well by the new institutional economics literature (Buchanan and Tullock 1962, North and Thomas 1973, North 1981, 1990). DeLong and Shleifer (1993) supplied early empirical support for this view using data on urbanization of European regions during the last millennium, which showed faster city growth under more limited governments. More recently, the literature on economic growth, starting with early contributions by Knack and Keefer (1995) and Mauro (1995), has turned to the effects of good institutions on economic growth. It is fair to say that recent work, including Hall and Jones (1999), Acemoglu, Johnson and Robinson (2001, 2002), Easterly and Levine (2003), Dollar and Kraay (2003), and Rodrik, Subramanian, and Trebbi (2002), has reached close to an intellectual consensus that the political institutions of limited government cause economic growth. 
The reverse idea, namely that growth in income and human capital causes institutional improvement, is most closely associated with the work of Seymour Martin Lipset (1960), who however himself gives credit to Aristotle. Lipset believed that educated people are more likely to resolve their differences through negotiation and voting than through violent disputes. Education is needed for courts to operate and to empower citizens to engage with government institutions. Literacy encourages the spread of knowledge about the government's malfeasance. According to this view, countries differ in their stocks of human and social capital - which can be acquired through policies pursued even by dictators - and institutional outcomes depend to a large extent on these endowments (see Djankov et al. 2003). This line of work seems to accord well with the experiences of South Korea, Taiwan, and China, which grew rapidly under one-party dictatorships, the first two eventually turning to democracy. Empirically, Lipset's hypothesis that growth leads to better political institutions -- has received considerable support in the work of Przeworski and his associates (Alvarez et al. 2000) and Barro (1999).

The two views of economic and political development share some important similarities. They both emphasize the need for secure property rights to support investment in human and physical capital, and they both see such security as a public policy choice. However, the institutional view sees the pro-investment policies as a consequence of political constraints on government, whereas the development view sees these policies in poor countries largely as choices of their - typically unconstrained -- leaders.

In this paper, we revisit these two broad approaches to development in an effort to assess each one's empirical validity. Our view is shaped to some extent by the experiences of North and South Korea, illustrated in Figure 1. Prior to the Korean war, the two countries were obviously part of one, so it is difficult to think of them as having different histories. They were both 
exceptionally poor in 1950. Between the end of the Korean war and 1980, both countries were dictatorships. If institutions are measured by Polity's "constraints on the executive," which as we discuss below is probably the best of the measures commonly used in the literature, then between 1950 and 1980 North Korea had an average score of 1.71, and South Korea 2.16 (out of 7). Yet South Korean dictators chose capitalism and secure property rights and the country grew rapidly, reaching per capita income level of US $\$ 1589$ in 1980. The North Korean dictator, in contrast, chose socialism, and the country only reached the level of income of US \$768 in 1980. Figure 1 also shows that, starting in 1980, South Korea transforms itself into a democracy, while North Korea remains a dictatorship. While on average, looking over the half century between 1950 and 2000, South Korea obviously had better institutions as measured by constraints on the executive, these institutions are the outcome of economic growth after 1950 rather than its cause. It would be wrong to attribute South Korea's growth to these institutions rather than the choices made by its dictators.

Our empirical analysis proceeds in five stages. In section II, we revisit three measures of "institutions" used in the current economic growth literature: risk of expropriation by the government, government effectiveness, and constraints on the executive. We show that the first two of these measures by construction do not describe political institutions: they are outcome measures that reflect the government's past restraint from expropriation in the first case, and its quality in the second. These measures do not code dictators who choose to respect property rights any differently than democratically elected leaders who have no choice but to respect them. Since these measures confound constraints on government with dictatorial choices, they do not proxy for institutions, which in their essence are constraints (North 1981). Moreover, these are both 
subjective measures which rise sharply with the level of economic development, raising severe doubts that the causality runs from them to growth rather than the other way around.

The third measure we consider, constraints on the executive, is in principle linked to constraints on government, but in reality is constructed to reflect the outcomes of most recent elections. In developing countries, even this measure is extremely volatile, and cannot be plausibly interpreted as reflecting durable rules, procedures or norms that the term "institutions" refers to. Indeed, we show that the three conventional measures of institutions are uncorrelated with constitutional constraints on government that scholars have just begun to use. All this evidence sheds doubt on the proposition that the measures of institutions used in the growth literature reflect any "deep" parameters that they are purported to measure.

In Section III, we discuss some of the basic OLS evidence on the relationship between institutions, human capital, and economic growth. We confirm the now well-established propositions that the initial level of human capital of a country, and the average level of its institutions over a period of time, predict its level of economic growth over that very same period of time. But, as section II shows, and the South Korean example illustrates, institutional quality rises as a country grows richer. In fact, we find that, in a variety of specifications, initial levels of constraints on the executive do not predict subsequent economic growth, whereas initial levels of human capital continue to be strong predictors. Thus even the OLS evidence is quite unsupportive of the proposition that constraints on the executive cause growth, and is supportive of the proposition that the more basic cause is human capital.

In section IV, we try to dig deeper into these issues by looking at the universe of poor countries as of 1960 . We find that virtually all of these countries had uneducated populations, and were moreover run by dictators. Indeed, most countries in this group have spent the vast majority 
of years since 1960 under dictators. These dictatorships had a large dispersion of growth rates, an observation itself inconsistent with the view that constraints on government shape growth experiences of poor countries. The near universality of dictatorships in poor countries suggests that the security of property in these countries is the result of policy choices, not constraints.

In Section V, we turn to one of the central strategies that researchers have used to establish the primacy of political institutions: instrumental variables. We discuss recent work of Acemoglu, Johnson, and Robinson (2001, 2002), which shows that, among European colonies, settler mortality and population density in 1500 predict institutional quality and the level of economic development today. We show, however, that these results do not establish a role for institutions. Specifically, the Europeans who settled in the New World may have brought with them not so much their institutions, but themselves, i.e., their human capital. This theoretical ambiguity is consistent with the empirical evidence as well. We show that the instruments used in the literature for institutions are even more highly correlated with human capital both today and in 1900, and that, in instrumental variable specifications predicting economic growth, human capital performs better than institutions. At the purely econometric level, this evidence suggests that predictors of settlement patterns are not valid instruments for institutions.

In Section VI, we conclude the empirical analysis by looking at the timing of human capital accumulation and institutional quality. We find evidence consistent with the example of South Korea, namely that economic growth and human capital accumulation cause institutional improvement, rather than the other way around.

Finally, Section VII concludes with some implications of our analysis. We find ourselves much closer to Lipset than to the new institutionalists. If the experience of poor countries in the last 50 years is a guide, politically constrained government may not be a viable strategy for them 
to secure property rights. Rather, these countries may need to emphasize economic policies and choices that ensure such security, even by dictators. Growth in these countries may be feasible without immediate institutional improvement, and is likely in turn to lead to institutional improvement. At least this is what the data show.

\section{The Measurement of Institutions.}

North (1981) defines institutions as "a set of rules, compliance procedures, and moral and ethical behavioral norms designed to constrain the behavior of individuals in the interests of maximizing the wealth or utility of principals" (p. 201-202). A key word that this and other definitions share is constraints. Thus constitutions or electoral rules are good examples of institutions, but good policies chosen by dictators who have a free hand are not. But there is another essential aspect of institutions noted even in dictionaries: the constraints need to be reasonably permanent or durable. Indeed, transitory "constraints" would not necessarily bind, and may be changed by those who do not like them. This permanency or "depth" of institutions has been relied on, for example, to justify using history as an instrument for institutional quality today (Rodrik et al. 2002). Thus legal systems or electoral rules look more like "institutions" when they are actually used over time, in contrast, for example, to the presidencies of Bill Clinton or George Bush, which most people would not regard as "institutions."

In this section, we discuss the measurement of political institutions used in recent research. We ask if these measures of institutions reflect a) constraints on government and b) permanent or at least durable features of the environment. We show that, in fact, they reflect neither.

To measure institutions, the literature has focused on several sets of variables. Here we discuss three. The first set, used initially by Knack and Keefer (1995) and Hall and Jones (1999), 
and more recently by Acemoglu, Johnson, and Robinson (2001), are survey indicators of institutional quality from the International Country Risk Guide, collected over the 1980s and 1990s. The second set, used most recently by Rodrik, Subramanian, and Trebbi (2002), is an aggregated index of mostly survey assessments of government effectiveness collected by Kaufmann, Kraay, and Mastruzzi (2003). The third set, coming from the Polity IV data set collected by political scientists (Jaggers and Marshall 2000), aims directly to measure the limits of executive power.

Below we discuss these measures of institutions. We make three distinct points. First, all three data sets measure outcomes, not some permanent characteristics that North refers to. As such, all these measures 1) rise with per capita income, and 2) are highly volatile. Both of these facts are inconsistent with the view that they measure permanent or even durable features of the political environment. Second, the first two sets of measures of institutions are constructed so that dictators freely choosing good policies receive as high evaluations as governments constrained to choose them. An examination of these variables shows, for example, that dictators who chose to respect property rights - in the U.S.S.R. or Singapore, for example -- received high scores, which the literature has interpreted as having "good institutions." Even if these measures are extremely useful indicators of policy choices, they are by their very construction not constraints, and therefore unusable for discussions of how specific constraints on government that would guarantee the security of property rights. The Polity IV variables are intended to focus on political constraints, but we show that they too reflect political outcomes rather than durable constraints.

Third, these measures of political institutions appear to be uncorrelated with the available constitutional measures of constraints on government coming from either electoral rules or courts. It is possible that these constitutional measures are noisy, and it is certain that "rules on the books" are very different from what actually takes place in a country. But this is precisely the point: the 
institutional outcomes that scholars have used as measures of constraints have very little to do with the constitutional constraints, raising doubts about the effectiveness of changing political rules.

Begin with the data from ICRG. The data include subjective assessments of risk for international investors along such dimensions as law and order, bureaucratic quality, corruption, risk of expropriation by the government, and risk of government contract repudiation. Of all three data sets, this one is probably the most problematic. It is plain that these measures reflect what actually happened in a country rather than some permanent rules of the game. For example, in 1984, the top ten countries with the lowest expropriation risk include Singapore and the U.S.S.R.. In these cases, the data obviously reflect the choices of dictators and not political constraints. Along similar lines, the data show a bizarre reduction in the risk of expropriation over time. Between 1982 and 1997, Iran moves from the score of 1 (highest expropriation risk) to 9 (close to the top score of 10), Libya from 1.5 to 9 , and Syria from 1.5 to 9 . We are not familiar with significant institutional constraints on the leaders of Iran, Libya, and Syria, although of course in the last few years these dictators had stayed away from expropriation and the data reflect their choices. Indeed, consistent with the intellectual victory of the Washington Consensus, the data show that the average score on expropriation risk in the sample rises from 5 in 1982 to 9 (with the median of 9.5) in 1997. Whatever expropriation risk measures, it is obviously not permanent rules, procedures, or norms supplying checks and balances on the sovereign.

The Kaufmann, Kraay, and Zoido-Labaton (2002) "government effectiveness" variable is likewise a clear outcome measure. Starting in 1996, these authors have aggregated a large number of subjective assessments of institutional quality into broad indices of government effectiveness. "In Government Effectiveness, we combine perceptions of the quality of public service provision, the quality of the bureaucracy, the competence of civil servants, the independence of the civil 
service from political pressures, and the credibility of the government's commitment to policies into a single grouping" (p. 8). These are clear ex-post outcomes, highly correlated with the level of economic development, rather than political constraints per se. Indeed, the country that receives the highest score in the world is Singapore, a state known both for its one party rule and for this party's chosen respect for private property.

Polity IV data make the greatest attempt at measuring the political environment rather than dictatorial choices. Constraints on the executive refers to "the extent of institutionalized constraints on the decision-making powers of chief executives, whether individuals or collectivities." The highest score for this variable is 7 , the lowest is 1 . The rich democracies, but also countries like Botswana, India, and South Africa, tend to get the perfect score of 7. Dictatorships like Cuba, Iraq, North Korea, but also Pinochet's Chile get the worst score of 1, the communist countries such as China and U.S.S.R. are in the middle with 3's. It is difficult to see how property is more secure in Mao's China than in Pinochet's Chile, but at least it is clear what the variable is trying to get at. The concern of this variable is, according to its creators, with the checks and balances between the various parties in the decision making process. However, a closer look at how this variable is constructed immediately reveals that it is an outcome measure, which reflects not the constraints, but what happened in the last election. When countries have inconsistent electoral experiences, their scores fluctuate wildly. For example, Haiti gets the worst score of 1 under the dictatorship during 1960-1989, jumps up to 6 when Aristide is elected in 1990, goes back to 1 when he is ousted during 1991-1993, rises again to 6 and even a perfect score of 7 during 1994-1998 as Aristide and his party return to power (even though the elections had been widely criticized), but falls down all the way to 3 during 2000-2001. Likewise, Argentina fluctuates between the worst scores under generals, and the best ones after elections, even when the elected leaders undermine 
the legislature and courts. The data make it obvious that Polity IV provides a rapidly moving assessment of electoral outcomes over time, not a measure of actual political constraints on government, and certainly not a measure of anything permanent or durable. And to the extent that, in richer countries, elections are likely to be cleaner, "constraints on the executive" may well be a consequence of development rather than the other way around.

Likewise, the measure of "democracy" in Polity IV reflects the extent to which "the three essential, interdependent elements" are actually adhered to. These include "the presence of institutions and procedures through which citizens can express effective preference about alternative policies and leaders, the existence of institutional constraints of the exercise of power by the executive (see above), and the guarantee of civil liberties to all citizens in their daily lives and in acts of political participation." Although the definition is intended to suggest some permanence, the construction of the variable, like that of the previous measure, reflects most recent experiences.

In Tables 1 and 2, we illustrate the "outcome" nature of even the Polity IV measures. Table 1 shows the average within-country deviations of five variables: autocracy (from Alvarez et al. 2000, based on Polity), constraints on the executive from Polity, democracy from Polity, autocracy from Polity, and, for comparison, Barro's measure of years of schooling. Due to data availability, all variables are measured every five years, between 1960 and 2000. All individual year observations are normalized to lie between zero and 1 to make comparison easier. Table 1 shows that even the Polity variables are twice as volatile as the measure of human capital. If constancy is a measure of depth, then human capital is "deeper" than institutions.

Table 2 looks at persistence of human capital and politics by regressing 2000 values of the political variables on their 1960 values. We find that education is much more persistent than the measures of constraints on the executive from Polity. The amount of mean reversion in political 
institutions is stunning, suggesting that these variables can hardly be used as assessments of "deep" or "permanent" features of the political landscape.

The fact that the measures of institutions used in the literature reflect choices (often made by dictators) rather than constraints is further illustrated by examining the correlations between these variables and written constitutional rules. We consider four such measures. The first two are motivated by the work of Persson and Tabellini (2003) on electoral rules, which these authors see as one of the important constraints on executive authority. One such variable we use is "plurality", which equals one if legislators are elected using a winner-take-all/first past the post rule. The other objective measure is "proportional representation," which equals one if candidates to the upper and lower houses of parliament are elected using a proportional representation system. Both of these variables come from Beck et al. (2001). In addition, we use two constitutional measures of the checks on the executive supplied by the judiciary from La Porta et al. (2004). The first is judicial independence, which measures the permanency in office of supreme court judges. The second is constitutional review, which measures the extent of judicial review of legislation. Again, all these are constitutional measures of political rules constraining the executive.

Table 3 presents the correlations between the outcome measures used in the growth and institutions literature, per capita income in 2000, and objective institutional rules. For the traditional institutional measures, we follow the growth literature and use the averages computed over different time periods. Thus we use the 1960-2000 average for executive constraints, 1982 1997 average for expropriation risk, 1960-1990 average for the Alvarez et al. (2000) measure of autocracy, and the average of 1996, 1998, and 2000 values for government effectiveness. Judicial independence and constitutional review are available at only one point in time (in 1995), while plurality and proportional representation are averages over the period 1975-2000. 
Three results stand out. First, the traditional indices of institutional quality are strongly correlated with each other, as well as with per capita income. This result is consistent with institutions having a causal positive effect on growth, but also with reverse causality. Specifically, if institutional outcomes improve as a country grows richer, as they clearly do, then both the average and the end of period institutional assessments will be higher in richer countries. Second, plurality and proportional representation - both constitutional measures of constraints - are correlated with per capita income (as well as with the subjective measures), but the correlations are much smaller than those of the traditional indices. Third, the measures of judicial checks and balances - judicial independence and constitutional review - are uncorrelated with per capita income, and only judicial independence is weakly correlated with outcome indices. The weak correlations may mean either that these constitutional measures of constraints are noisy, or that the association between "institutions" and development comes from institutional outcomes being better in richer countries, rather than political rules creating wealth.

The bottom line of this section is that the commonly used measures of institutions cannot be used to establish causality. These measures are not constructed to reflect either constraints on government or permanent features of the political landscape. Instead, they are highly volatile and mean-reverting. They are barely correlated with the available objective measures of constitutional constraints on government. Yet these are the variables used to show that institutions cause growth.

\section{Political Institutions, Human Capital, and Economic Growth.}

Table 4 presents the standard OLS growth regressions using the various measures of political institutions we discussed above. As in the correlation Table 3, we follow the literature and use averages of the assessments of institutional quality over a period of time. In Table 4, the 
dependent variable is the growth of per capita income between 1960 and 2000, and the independent variables are initial income per capita (as suggested by Barro 1991), initial education, the share of a country's population in temperate zones, as well as eight institutional variables entering one at a time. The results confirm the now-standard observation of convergence, as well as the benign influence of temperate weather.

The results also show that the initial level of education is a strong predictor of subsequent economic growth. One interpretation of this result would support theories of growth in which human capital generates significant technological externalities (e.g., Lucas 1988). However, Pritchett (2000) summarizes evidence suggesting that economic returns to education in developing countries are not especially high. An alternative interpretation is along the lines of Lipset (1960), namely human capital leads to more benign politics, less violence, and more political stability. The key human capital externality is not technological but political: courts and legislatures replace guns. These improvements in turn bring about greater security of property and economic growth. This interpretation is consistent with the evidence of Alesina et al. (1996) that political stability predicts economic growth, and with many findings we discuss below.

Finally, the evidence shows a strong correlation between economic growth over a period and the average assessments of institutional quality over that period, including constraints on the executive, risk of expropriation, government effectiveness, and autocracy. In contrast, there is no relationship between growth and constitutional measures of institutions, such as judicial independence, constitutional review, plurality, and proportional representation. The contrast between the institutional outcome variables used in the growth literature, and the constitutional constraints on government, is striking. 
One reason that average assessments of institutions might enter significantly in the growth regressions is that these assessments improve as the economy gets richer, so the causality runs in reverse. Note, in contrast, that growth regressions typically use initial values of education. To further assess this possibility, Tables 5 and 6 present a series of growth regressions in which the independent variable is the executive constraints at the beginning of the period. We focus on executive constraints because it is the only measure that is clearly not a consequence of dictatorial choices, and hence, even though it reflects electoral outcomes, can at least loosely be thought of as relating to constraints on government.

Table 5 presents, starting in 1960, decade by decade growth regressions using initial period education, initial period per capita income, and initial period constraints on the executive, as independent variables. It also presents similar regressions for the whole period 1960-2000. (We have also obtained, but do not report, very similar results using 20-year intervals.) Table 5 shows that, even in the OLS specifications, initial executive constraints have no predictive power for subsequent economic growth outside the 1980s, whereas initial human capital is a strong predictor. These results exacerbate the concern over reverse causality when sample averages of institutional outcomes are used in growth specifications.

Table 6 takes advantage of the fact that data on executive constraints are available for a few countries as far back as the middle of the $19^{\text {th }}$ century, as are data on economic growth from Maddison (2003). We also have some data on primary school enrollments starting in 1870 from Lindert (2001). For these small samples, we can regress long term growth on initial executive constraints, initial income, and initial school enrollments. Again, there is no evidence that constraints on the executive predict growth, but some evidence that initial human capital does. 
The evidence presented in these tables on the relationship between institutions and growth leaves us skeptical about causality. Nonetheless, an advocate of institutional view might argue that the average political outcome over time is a good measure of durable constraints. If institutions reflect "deep" features of the environment, then even if constraints on the executive measure the cleanness of the last election, the average of such constraints over time is a good proxy for the "permanent" or "durable" constraints. It is then the average rather than the starting points that belongs in the growth regression. Moreover, human capital, being not as "deep" as the average of institutional outcomes, simply does not belong in the regression.

In light of the results we have brought out, this argument is not persuasive. First, the fact that even the Polity measures of institutions are more volatile and more mean reverting than years of schooling raises severe doubts that these variables, even if averaged, reflect anything more permanent than human capital. Second, this argument does not deal with the obvious point of reverse causality, and the fact that initial measures of political institutions, in just about any sample, seem to have no predictive power at all. Indeed, even if we follow the recommendation that constraints on the executive must be averaged, but regress ten year growth rates on the average constraints of the executive over the previous decade, these averages do not predict subsequent economic growth. The results are very similar to those in Table 5. Averaging itself, without regressing growth on contemporaneous average institutional quality, does not suggest that institutions predict growth. Third, the lack of correlation between even the average outcome measures and the constitutional constraints on government raises still further doubts that anything deep is being measured. In sum, while there might be (though certainly does not need to be) something "deep" about institutions, it is implausible to argue that the variables used in the standard growth regressions capture anything "deep". 
What do we learn from this analysis? To us, the principal conclusion is that, at least in the OLS regressions, the evidence that institutions cause economic growth, as opposed to growth improving institutions, is non-existent. The objective measures of institutions, those that actually describe the constitutional rules that limit the power of the sovereign, have no predictive power for the growth of per capita income. Even the beginning-of-period executive constraints have no predictive power. In contrast, the political variables that are correlated with development are themselves by construction a product of development. The OLS cross-country evidence for 19602000 provides no support for the claim that "institutions cause growth."

\section{Politics and Growth in Poor Countries After 1960.}

Growth regressions are one way to assess the effect of institutions on economic growth. Another way is to consider human capital and political institutions in the sample of poor countries circa 1960. To this end, we divide our 1960 sample of countries into those with low human capital (total years of schooling per capita below the median value of 2.68), intermediate human capital (schooling between 2.68 and 5.01 years per capita), and high human capital (schooling above the $75^{\text {th }}$ percentile value of 5.01 years per capita). We independently divide this sample into four types of political regimes using the 1960-2000 average Polity IV democracy score: autocracies (countries with the average score under 2), stable democracies (countries with the average perfect score of 10), and two intermediate groups: imperfect autocracies (the average score between 2 and 7 ) and imperfect democracies (the average score between 7 and 10). Autocracies include places like Saudi Arabia, Vietnam, and Yemen. Stable democracies cover all the usual developed countries (except that it includes Costa Rica but not France). 
Table 7 presents the number of observations in each of the 12 cells using the two independent classifications. Nearly all highly educated countries are stable democracies (score $=$ 10), and nearly all stable democracies are highly educated. (The two stable democracies with intermediate human capital are Italy and Costa Rica.) In contrast, nearly all dictatorships are poorly educated; the only dictatorships with the intermediate level of human capital are Paraguay, Singapore, and Taiwan. Put differently, the lowest education countries are never stable democracies; the highest education countries are generally stable, but sometimes imperfect, democracies. Consistent with Lipset, over the last 40 years, politics has been much more benign in well-educated, than in poorly educated, countries.

Are these differences between educated and uneducated countries reflected in the growth rates as well? Table 8 presents the data on average growth rates of different groups of countries. During 1960-2000, countries with high human capital in 1960 have grown 2 times faster, on average, than low human capital ones. Stable democracies have grown slightly faster than imperfect democracies, and much faster than dictatorships, on average, but this may of course be just the human capital effect. In addition, Table 8 shows the dispersion of growth rates among different groups of countries. It shows the higher dispersion of growth rates across autocracies than democracies, and across poorly educated countries relative to the well educated ones.

The evidence in Tables 7 and 8 leads to another reason for skepticism about the primacy of political constraints for economic development: although nearly all poor countries in 1960 were dictatorships, some of them have managed to get out of poverty, while others stayed poor. This kind of evidence is at least suggestive that it is the choices made by the dictators, rather than the constraints on them, that have allowed some poor countries to emerge from poverty. If being a stable democracy, with all the effective constitutional constraints on the executive, is not an option 
for a poor country, and if dictatorship is the more likely political path, then it is crucial to understand what makes for a successful dictatorship.

This suggestion receives a further boost from a simple characterization of who actually leads the less educated countries over time. In Table 9, we continue to separate countries into those with low and moderate levels of human capital, as before. We then classify for each year the country's leader along two dimensions. We follow the Alvarez et al. (2000) classification of leaders as being democratic or autocratic. In addition, we group the leaders by the length of their tenure. The Table shows the amount of time spent by countries in our sample being led by democratic and autocratic leaders of different tenure lengths.

The least educated countries are overwhelmingly led by long-standing dictators. For 66 percent of the years in our sample, these countries are led by autocratic leaders who eventually last for at least five years. For 50 percent of the years in our sample, these countries are led by autocrats who eventually last for at least ten years. In contrast, only 6 percent of the time are the least-educated countries led by democratic leaders with terms that end up being less than five years, and only 13 percent of the time, these countries are run by democratically elected leaders that last for more than five years. Among moderately well educated countries, the situation is more mixed. About 43 percent of the time, these countries are governed by democratically elected leaders. For 32 percent of the time, they are governed by democratic leaders who last between 2 and 10 years in office. In contrast, these countries are governed by dictators who last for more than 5 years for 44 percent of the time in the sample. Yet, the dictatorship that lasts for more than 10 years is still the largest single grouping in the table (32 percent).

This evidence is at most suggestive. But it does suggest that, from the point of view of understanding the emergence of countries from poverty, the focus on placing constraints on 
government as a starting reform may have been misplaced. The focus on factor accumulation, including the growth in human capital, might have been more productive.

\section{Instrumental Variables.}

From the beginning, the growth and institutions research recognized that growth may itself lead to better institutions. One way in which this literature tried to address this problem is instrumental variables. Mauro (1995) already recognizes these issues, and uses ethnolinguistic fractionalization of the population as an instrument for corruption. Hall and Jones (1999) use ICRG measures of institutional quality, but instrument them using "distance from the equator and the extent to which the primary languages of Western Europe are spoken today" (p. 110). Researchers also tried to take advantage of the fact that the European expansion influenced the countries being conquered and colonized. La Porta et al. $(1997,1998,1999)$ take advantage of this colonial experiment by looking at legal transplantation. They argue that Europeans brought their legal systems into the countries they conquered or colonized, and that therefore legal origin can be used as an instrument for the structure of various laws.

This line of research was subsequently given a substantial boost by a pair of recent papers by Acemoglu, Johnson, and Robinson $(2001,2002)$. These authors argue that central to understanding each country's political institutions is not what laws the Europeans brought, but rather whether they themselves settled in the particular colonies. AJR (2001) argue that the mortality of European settlers in the countries they colonized shaped their decision to settle or not. When the Europeans settled, they brought with them the effective European institutions constraining the executive, whereas when they did not settle, they instituted systems of arbitrary rule and expropriation of local populations. AJR (2002) further argue that the density of non- 
European populations in the prospective colonies shaped the European settlement patterns. When a region was densely settled (or urbanized) by the locals, the Europeans did not settle themselves, but rather introduced exploitative institutions. In low density areas, in contrast, they settled and brought their institutions of limited government, thereby causing long run growth. Using this logic, $\operatorname{AJR}(2001,2002)$ argue that both settler mortality and indigenous population density in 1500 can be used as instruments for modern day political institutions constraining the executive.

The AJR papers invigorated the institutions and growth literature. Below we discuss their work. But, as a starting point, it is important to note that, even if one agrees that mortality risk or indigenous population density shaped the European settlement decisions, it is far from clear that what the Europeans brought with them when they settled is limited government. It seems at least as plausible that what they brought with them is themselves, and therefore their know-how and human capital. (This is the interpretation of the effects of settler mortality suggested theoretically by Djankov et al. (2003)). If that is the case, then at a purely conceptual level one cannot infer from the patterns of European settlement that the asset being transplanted is institutions. To put the same point in econometric terms, valid instruments must be uncorrelated with the error term, and if settlement patterns influence growth through channels other than institutions, they are not valid instruments. As we suggest below, this observation has significant implications for the interpretation of instrumental variables regressions of growth on institutions.

The correlation between AJR's proposed instruments and their preferred measures of institutions is very high indeed. For example, the logarithm of settler mortality is correlated at -.54 with average executive constraints, and -.51 with average expropriation risk, while the logarithm of population density in $1500 \mathrm{~s}$ is correlated at -.35 and -.40 with the same measures of institutions. 
But are AJR's proposed instruments valid? We have several concerns, some already discussed in the literature, but some new and perhaps more important. First, settler mortality is basically uncorrelated with the constitutional measures of checks and balances we discussed in Section II, and the logarithm of 1500 population density is only very weakly correlated with plurality and proportional representation. If the Europeans really brought their institutions constraining government, one might expect this influence to be reflected in "rules and procedures," yet this does not appear to be the case in the data. This is also surprising in light of all the available evidence that colonial transplantation of legal traditions - the ultimate rules and compliance procedures -- has been central in shaping the legal and regulatory systems of the receiving countries. Why would colonial influence on rules and procedures be so strong in one case, but not in the other?

Second, an important element of the AJR line of reasoning is that settler mortality reflects past settlement policies and their modern consequences. Yet the instruments appear to be correlated with the modern disease environment as well. Jeffrey Sachs and his associates (Gallup et al. 2001, Kiszewski et al. 2004) present data on modern malaria risk and malaria ecology. The correlation of the log of settler mortality with malaria risk is .67, and with malaria ecology it is .66. The $\log$ of 1500 population density, however, has a correlation of .38 with malaria risk, but only .14 with malaria ecology. These correlations raise the question of whether AJR instruments reflect the historical rather than the modern disease environment, since the latter might have an independent affect on human capital, development, and institutions.

AJR are well aware of this concern. As a test, they regress their preferred institutional variables on settler mortality and malaria together, and find that settler mortality but not modern malaria is statistically significant. Table 10 presents the results of similar regressions using all 
available observations (AJR use a subset). Our results are different from those reported in their work. The impact of settler mortality on today's institutions remains significant, but so is that of malaria risk. At least part of what settler mortality captures is the modern disease environment. These results suggest that the issue of modern disease environment is real, and one should exercise caution in treating AJR instruments as proxies for the colonial but not modern mortality risk.

Still, both settler mortality and 1500 population density are strongly correlated with today's per capita income. Why might this be so? This gets us to our third and crucial point. A necessary condition for these variables to be valid instruments for institutions is that they not influence per capita income through other channels, i.e., be uncorrelated with the error term. We have seen that human capital is an important determinant of economic growth. The importance of malaria in determining current income points in the same direction. Could the influence of AJR's proposed instruments on today's development work through human capital? Put differently, perhaps when colonizers settled, they brought with them their know-how rather than constraints on the executive.

Figures 2-5 show the relationship between settler mortality and 1500 population density on the one hand, and total years of schooling in 1960 and 2000 on the other. These correlations are even stronger than those between settler mortality and the measures of institutions. For example, the correlation between settler mortality and years of schooling in 2000 is -.73 .

Some additional evidence on the importance of human capital, and its relationship to the proposed instruments, comes from the small sample of countries for which we have data on primary school enrollments in 1900. Figure 6 shows that this measure of educational investment a century ago is a strong predictor of the level of economic development today. Figures 7 and 8 further show that this measure of education is strongly negatively correlated with the proposed AJR 
instruments. This evidence may further suggest that human capital, both today and as historically introduced by the colonizers, drives economic growth.

Table 11 further investigates the effects of human capital and political institutions in the instrumental variables framework. We present the first and second stage results from the IV estimation of the impact of average years of schooling between 1960 and 2000, and average executive constraints over the same period, on log GDP per capita in 2000. As instruments, we use French legal origin, log settler mortality, and $\log 1500$ population density (the last two used one at a time). The AJR instruments are important determinants of both executive constraints and years of schooling in the first-stage regressions, while French legal origin countries have a lower level of constraints on the executive, consistent with La Porta et al. (1999). In the second-stage regression, however, the predicted years of schooling are a statistically significant determinant of per capita income, but executive constraints are not. If anything, in the IV framework human capital seems to be a more important variable predicting development than political institutions.

We do not wish to push these results too far. By our own logic, human capital and institutions are not the only potentially important baggage that the European colonizers have brought with them, and so the instrument might still be correlated with the error term. They brought "guns, germs, and steel" among other things (Diamond 1997, Engerman and Sokoloff 1991). The effects of colonial settlement work through many channels, and the instruments used in the literature do not tell us which channel matters. Even if one accepts the view that the variables proposed by AJR $(2001,2002)$ shaped the European settlement patterns, the data do not tell us whether the Europeans brought with them their human capital, political institutions, or something else. The instrumental variable approach does not tell us what causes growth. 


\section{From Schooling to Institutions}

As a final way to understand whether schooling or institutional outcomes come first, we follow Barro $(1997,1999)$ and look at timing. If institutions come first, then lagged values of political variables should predict improvements in education. If education is the critical input, then lagged values of education should predict improvement in institutional outcomes. In the top Panel of Table 12, we regress, using five-year intervals, growth in years of schooling on country fixed effects, initial schooling, and initial measures of political institutions used in the growth literature as well as the initial level of GDP per capita. The data show some mean reversion in schooling (perhaps due to measurement error), a large and positive effect of initial level of income on the growth of education, and no effect of initial political institutions, no matter how measured, on the growth of human capital.

In the bottom panel, we look at the changes in political institutions over five-year intervals as a function of country fixed effects, initial schooling, initial level of economic development, and initial levels of these political institutions themselves. The results are striking. Initial levels of schooling are a strong predictor of improving institutional outcomes over the next five years using 3 out of 4 measures, including executive constraints. Initial per capita income has no predictive power. And, as we saw before, there is a lot of mean reversion in these measures of institutions.

As before, we do not want to take these results as dispositive. However, they are strikingly consistent with the Lipset view that high human capital leads to institutional improvement, even over a relatively short horizon of 5 years. Moreover, like many of the earlier findings we presented, the results are inconsistent with the view that high assessments of political institutions predict subsequent improvement in the years of schooling. 


\section{Conclusion.}

Exploring the causal link between institutions and economic growth has proved extremely difficult. Despite creative and insightful efforts, the existing research strategy does not establish this link, due to both conceptual problems with the measurement of institutions and the limitations of econometric techniques. In particular, the existing research does not show that political institutions rather than human capital have a causal effect on economic growth. Indeed, much evidence points to the primacy of human capital for both growth and democratization.

Our results are consistent with a perspective on institutions outlined by Djankov et al. (2003). According to that paper, each community faces a set of institutional opportunities, determined largely by the human and social capital of its population. The greater the human and social capital of a community, the more attractive its institutional opportunities. Institutions, in this framework, are points on this opportunity set, determined by efficiency, history, and politics. Institutions are highly persistent because history, including colonial history, shapes social choices. But institutional outcomes also get better as the society grows richer, because institutional opportunities improve. Importantly, in that framework, institutions have only a second order effect on economic performance. The first order effect comes from human and social capital, which shape both institutional and productive capacities of a society.

Our results have some implications for economic research and for economic policy. They suggest that research in institutional economics, and in particular on the consequences of alternative institutional arrangements, must focus on actual rules, rather than on conceptually ambiguous assessments of institutional outcomes. The results of this paper do not show that "institutions do not matter." That proposition is flatly contradicted by a great deal of available empirical evidence, including our own. Rather, our results suggest that the current measurement strategies have 
conceptual flaws, and that researchers would do better focusing on actual laws, rules, and compliance procedures that could be manipulated by a policy maker to assess what works .

With respect to policy, our results do not support the view that, from the perspective of security of property and economic development, democratization and constraints on government must come first. In many poor countries, such security came from policy choices made by dictators. The economic success of East Asia in the post war era, and of China most recently, has been a consequence of good-for-growth dictators, not of institutions constraining them. Indeed, the Chinese example illustrates this point forcefully: there was nothing pre-destined about Deng, one of the best dictators for growth, succeeding Mao, one of the worst. More generally, it might be less profitable to look for the "deep" factors explaining economic development than for policies favoring human and physical capital accumulation (see also Przeworski 2004a,b).

None of this is to deny the merits of democracy and the constraints on government as essential human values in their own right. Mulligan, Gil, and Sala-i-Martin (2004) present compelling evidence that in such policy areas as freedom of the press, torture, death penalty, and regulation of religion, democracies are significantly more benign than dictatorships. But our evidence suggests some skepticism about the viability of democracy in countries with low level of human capital - there have been few examples of such democracies in the world. Our evidence suggests in contrast that the Lipset-Przeworski-Barro view of the world is more accurate: countries that emerge from poverty accumulate human and physical capital under dictatorships, and then, once they become richer, are increasingly likely to improve their institutions. 


\section{Bibliography}

Acemoglu, Daron, Simon Johnson, and James A. Robinson. 2001. “The Colonial Origins of Comparative Development: An Empirical Investigation," American Economic Review 91(5): 1369-401.

Acemoglu, Daron, Simon Johnson, and James A. Robinson. 2002. "Reversal of Fortune: Geography and Development in the Making of the Modern World Income Distribution," Quarterly Journal of Economics 117(4), 1231-1294.

Alesina, Alberto, Sule Ozler, Nouriel Roubini, and Phillip Swagel. 1996. "Political Instability and Economic Growth, ”Journal of Economic Growth 1(2): 189-212.

Alvarez, Michael, José A. Cheibub, Fernando Limongi and Adam Przeworski. 2000. Democracy and Development: Political Institutions and Material Well-Being in the World, 1950-1990. Cambridge: Cambridge University Press.

Aten, Bettina, Alan Heston and Robert Summers. 2002. Penn World Tables Version 6.1. Center for International Comparisons at the University of Pennsylvania (CICUP).

Barro, Robert J. 1991 "Economic Growth in a Cross-Section of Nations," Quarterly Journal of Economics 106(2): 407-43.

Barro, Robert J. 1997. Determinants of Economic Growth. Cambridge, MA: MIT Press.

Barro, Robert J. 1999. “Determinants of Democracy,” Journal of Political Economy 107(6-2): 158183.

Barro, Robert J. and Jong-Wha Lee. 2000. "International Data on Educational Attainment: Updates and Implications” Working Paper 42. Center for International Development (February).

Beck, Thorsten, George Clarke, Alberto Groff, Philip Keefer and Patrick Walsh. 2001. "New Tools in Comparative Political Economy: The Database of Political Institutions" World Bank Economic Review 15(1): 165-76.

Center for International Development, Geography Data sets. Found online at: $<$ http://www2.cid.harvard.edu/ciddata/geographydata.htm\#General\%20measures\%20of\%20 geography>

DeLong, J. Bradford and Andrei Shleifer. 1993. "Princes and Merchants: City Growth before the Industrial Revolution." Journal of Law and Economics 36(2): 671-702.

Diamond, Jared. 1997. Guns, Germs, and Steel. New York: Norton. 
Djankov, Simeon, Rafael La Porta, Florencio Lopez-de-Silanes and Andrei Shleifer. 2003. "The New Comparative Economics," Journal of Comparative Economics 31(4), 595-619.

Dollar, David and Aart Kraay. 2003. "Institutions, Trade and Growth." Journal of Monetary Economics 50(1): 133-62.

Easterly, William and Ross Levine. 2003. "Tropics, germs, and crops: how endowments influence economic development." Journal of Monetary Economics 50(1): 3-39.

Engerman, Stanley, and Kenneth Sokoloff. 1991. "Factor Endowments, Institutions, and Differential Paths of Growth among New World Economies," in Stephen Haber (ed.), How Latin America Fell Behind, Stanford, CA: Stanford University Press.

Gallup, John L. and Jeffrey D. Sachs. 2001. "The Economic Burden of Malaria.” The Supplement to The American Journal of Tropical Medicine \& Hygiene, 64(1-2): 85-96.

Hall, Robert E. and Charles I. Jones. 1999. "Why Do Some Countries Produce so Much More Output per Worker than Others?" Quarterly Journal of Economics, 114(1): 83-116.

International Country Risk Guide. (Political Risk Services, East Syracuse, NY, 1996).

Jaggers, Keith and Monty G. Marshall, 2000. "Polity IV Project" Center for International Development and Conflict Management, University of Maryland.

Jones, Benjamin and Benjamin Olken. 2003 "Do Leaders Matter? National Leadership and Growth since World War II.” Monograph, Harvard University.

Kaufmann, Daniel, Aart Kraay and Massimo Mastruzzi. 2003. "Governance Matters III: Updated Governance Indicators for 1996-02.” Working Paper Draft for comments. Washington, D.C.: World Bank.

Kaufmann, Daniel, Aart Kraay and Pablo Zoido-Lobatón. 2002. “Governance Matters II: Updated Governance Indicators for 2000-01” Working Paper No. 2772. World Bank Policy Research Department (February).

Kiszewski, Anthony, Andrew Mellinger, Pia Malaney, Andrew Spielman, Sonia Ehrlich, Jeffrey D. Sachs. 2004. "A Global Index of the Stability of Malaria Transmission Based on the Intrinsic Properties of Anopheline Mosquito Vectors." American Journal of Tropical Medicine and Hygiene. Forthcoming.

Knack, Steven and Philip Keefer. 1995. "Institutions and Economic Performance: Cross-Country Tests Using Alternative Measures.” Economics and Politics 7(3): 207-27. 
La Porta, Rafael, Florencio Lopez-de-Silanes, Andrei Shleifer, and Robert Vishny. 1997. "Legal Determinants of External Finance," Journal of Finance 52(3), 1131-1150.

La Porta, Rafael, Florencio Lopez-de-Silanes, Andrei Shleifer, and Robert Vishny. 1998. "Law and Finance," Journal of Political Economy 106(6), 1113-1155.

La Porta, Rafael, Florencio Lopez-de-Silanes, Andrei Shleifer, and Robert Vishny. 1999. "The Quality of Government," Journal of Law, Economics, and Organization 15(1) 222-79.

La Porta, Rafael, Florencio Lopez-de-Silanes, Christian Pop-Eleches and Andrei Shleifer. 2004. "Judicial Checks and Balances." Journal of Political Economy 112(2), 445-470.

Lindert, Peter H. 2001. "Democracy, Decentralization, and Mass Schooling before 1914" working paper 104. San Diego, California: University of California Agricultural History Center (February).

Lipset, Seymour M. 1960. Political Man: The Social Basis of Modern Politics. New York: Doubleday.

Lucas, Robert E. 1988. "On the Mechanics of Economic Development." Journal of Monetary Economics 22(1): 3-42.

Maddison, Angus. 2003. The World Economy: Historical Statistics. Paris: OECD.

Mauro, Paolo, 1995, "Corruption and Growth," Quarterly Journal of Economics, 110: 681-712.

McEvedy, Colin and Richard Jones. 1978. Atlas of World Population History. Viking Press.

Montesquieu, Charles de Secondat. 1748. The Spirit of the Laws. Paris.

Mulligan, Casey, Ricard Gil, and Xavier Sala-i-Martin. 2004. "Do Democracies Have Different Public Policies than Nondemocracies?", Journal of Economic Perspectives 18(1): 51-74.

North, Douglass C. 1981. Structure and Change in Economic History. New York: Norton \& Co.

North, Douglass C. 1990. Institutions, Institutional Change, and Economic Performance. Cambridge: Cambridge University Press.

North, Douglass C. and Robert P. Thomas. 1973. The Rise of the Western World: A New Economic History. Cambridge: Cambridge University Press.

Persson, Torsten and Guido Tabellini. 2003. The Economic Effects of Constitutions. Cambridge, Mass.: MIT Press.

Pritchett, Lant. 2000. "Where has all the education gone?" World Bank Economic Review 15(3). 
Przeworski, Adam. 2004a. "The Last Instance: Are Institutions the Primary Cause of Economic Development?” Mimeo, New York University.

Przerworski, Adam. 2004b. “Georgraphy vs Institutions Revisited: Were Fortuntes Reversed?”. Mimeo, New York University.

Rodrik, Dani, Arvind Subramanian and Francesco Trebbi, 2002. "Institutions Rule: The Primacy of Institutions over Geography and Integration in Economic Development." NBER Working Paper 9305, National Bureau of Economic Research (October).

Smith, Adam. 1976 [1776]. An Inquiry into the Nature and Causes of the Wealth of Nations, edited by Edwin Canaan. Chicago, Illinois: University of Chicago Press.

World Health Organization. 1997. "World Malaria Situation in 1994, Part I," WHO Weekly Epidemiological Record 36: 269-74. 


\section{Table 1}

\section{Volatility of political institutions and human capital}

The table shows the average within-country standard deviation of various measures of political institutions and human capital. Due to data availability, we measure human capital (years of schooling) and the Polity IV variables of political institutions in 1960, 1965, 1970, 1975, 1980, 1985, 1990, 1995 and 2000. We measure the autocracy variable from Alvarez et al. (2000) for 1960, 1965, 1970, 1975, 1980, 1985 and 1990 only because their data ends at that point. All variables were normalized to vary between 0 and 1 . All variables are defined in Appendix 1.

\begin{tabular}{|c|c|c|c|c|}
\hline \multicolumn{3}{|c|}{ Polity IV } & Alvarez et al. (2000) & \\
\hline $\begin{array}{l}\text { Executive constraints } \\
\qquad(1960-2000)\end{array}$ & $\begin{array}{l}\text { Democracy } \\
(1960-2000)\end{array}$ & $\begin{array}{c}\text { Autocracy } \\
(1960-2000)\end{array}$ & $\begin{array}{c}\text { Autocracy } \\
(1960-1990)\end{array}$ & $\begin{array}{c}\text { Years of schooling } \\
(1960-2000)\end{array}$ \\
\hline
\end{tabular}

Average within-country standard deviation

$\begin{array}{lllll}18.53 \% & 17.52 \% & 19.36 \% & 18.86 \% & 10.33 \%\end{array}$


Table 2

\section{Persistence of political institutions and human capital}

The table shows OLS regressions for the cross-section of countries. The specifications include a constant but we do not report the estimates in the table. Robust standard errors are shown in parentheses. All variables are defined in Appendix 1.

\begin{tabular}{|c|c|c|c|c|}
\hline & \multicolumn{4}{|c|}{ Dependent variables: } \\
\hline & $\begin{array}{c}\text { Years of } \\
\text { schooling } \\
(2000)\end{array}$ & $\begin{array}{c}\text { Executive } \\
\text { constraints } \\
(2000)\end{array}$ & $\begin{array}{c}\text { Autocracy -- } \\
\text { Polity IV } \\
(2000)\end{array}$ & $\begin{array}{c}\text { Democracy } \\
(2000)\end{array}$ \\
\hline Years of schooling (1960) & $\begin{array}{c}1.1773^{\mathrm{a}} \\
(0.0885)\end{array}$ & & & \\
\hline Executive constraints (1960) & & $\begin{array}{l}0.2719^{b} \\
(0.1246)\end{array}$ & & \\
\hline Autocracy -- Polity IV (1960) & & & $\begin{array}{c}0.1810^{c} \\
(0.0926)\end{array}$ & \\
\hline Democracy (1960) & & & & $\begin{array}{c}0.3065^{b} \\
(0.1341)\end{array}$ \\
\hline Observations & 50 & 50 & 50 & 50 \\
\hline $\mathrm{R}^{2}$ & 0.73 & 0.09 & 0.07 & 0.10 \\
\hline
\end{tabular}

$\mathrm{a}=$ significant at 1 percent; $\mathrm{b}=$ significant at 5 percent; $\mathrm{c}=$ significant at 10 percent. 
Table 3

\section{Correlations of measures of institutions}

\begin{tabular}{|c|c|c|c|c|c|c|c|c|}
\hline & $\begin{array}{l}\text { Log GDP per } \\
\text { capita }(2000)\end{array}$ & $\begin{array}{c}\text { Executive } \\
\text { constraints } \\
(1960-2000)\end{array}$ & $\begin{array}{c}\text { Expropriation } \\
\text { risk } \\
(1982-1997) \\
\end{array}$ & $\begin{array}{c}\text { Autocracy -- } \\
\text { Alvarez } \\
(1960-1990) \\
\end{array}$ & $\begin{array}{c}\text { Government } \\
\text { effectiveness } \\
(1998-2000) \\
\end{array}$ & $\begin{array}{c}\text { Judicial } \\
\text { independence } \\
(1995) \\
\end{array}$ & $\begin{array}{c}\text { Constitutional } \\
\text { review } \\
(1995) \\
\end{array}$ & $\begin{array}{c}\text { Plurality } \\
(1975-2000)\end{array}$ \\
\hline Executive constraints (1960-2000) & $0.7119^{\mathrm{a}}$ & & & & & & & \\
\hline Expropriation risk (1982-1997) & $0.7906^{\mathrm{a}}$ & $0.6378^{\mathrm{a}}$ & & & & & & \\
\hline Autocracy -- Alvarez (1960-1990) & $-0.7388^{\mathrm{a}}$ & $-0.8567^{\mathrm{a}}$ & $-0.6864^{\mathrm{a}}$ & & & & & \\
\hline Government effectiveness (1998-2000) & $0.7860^{\mathrm{a}}$ & $0.6349^{\mathrm{a}}$ & $0.8297^{\mathrm{a}}$ & $-0.5908^{\mathrm{a}}$ & & & & \\
\hline Judicial independence (1995) & 0.0279 & $0.3465^{\mathrm{a}}$ & $0.2629^{\mathrm{b}}$ & -0.1907 & $0.3006^{\mathrm{b}}$ & & & \\
\hline Constitutional review (1995) & -0.0649 & 0.1904 & 0.1189 & -0.0278 & 0.0482 & $0.2243^{\mathrm{c}}$ & & \\
\hline Plurality (1975-2000) & $-0.2620^{\mathrm{a}}$ & $-0.3570^{\mathrm{a}}$ & $-0.1918^{\mathrm{b}}$ & $0.2472^{\mathrm{a}}$ & $-0.2044^{\mathrm{a}}$ & -0.0992 & 0.0040 & \\
\hline Proportional representation (1975-2000) & $0.2947^{\mathrm{a}}$ & $0.3158^{\mathrm{a}}$ & $0.2172^{\mathrm{b}}$ & $-0.2151^{\mathrm{b}}$ & $0.2052^{\mathrm{b}}$ & -0.1684 & 0.1284 & $-0.6118^{\mathrm{a}}$ \\
\hline
\end{tabular}

$\mathrm{a}=$ significant at 1 percent; $\mathrm{b}=$ significant at 5 percent; $\mathrm{c}=$ significant at 10 percent. 


\section{Table 4}

\section{Economic growth, political institutions and human capital}

The table shows OLS regressions for the cross-section of countries. The dependent variable in all specifications is the growth of GDP per capita for the period 19602000. The specifications include a constant but we do not report the estimates in the table. Robust standard errors are shown in parentheses. All variables are defined in Appendix 1.

\begin{tabular}{|c|c|c|c|c|c|c|c|c|}
\hline & \multicolumn{8}{|c|}{ Dependent variable is growth of GDP per capita 1960-2000 } \\
\hline Log GDP per capita (1960) & $\begin{array}{l}-0.0114^{\mathrm{a}} \\
(0.0033)\end{array}$ & $\begin{array}{c}-0.0136^{\mathrm{a}} \\
(0.0033)\end{array}$ & $\begin{array}{c}-0.0112^{\mathrm{a}} \\
(0.0033)\end{array}$ & $\begin{array}{c}-0.0122^{\mathrm{a}} \\
(0.0033)\end{array}$ & $\begin{array}{c}-0.0141^{\mathrm{a}} \\
(0.0037)\end{array}$ & $\begin{array}{c}-0.0130^{\mathrm{a}} \\
(0.0037)\end{array}$ & $\begin{array}{c}-0.0090^{\mathrm{a}} \\
(0.0034)\end{array}$ & $\begin{array}{r}-0.0105^{\mathrm{a}} \\
(0.0036)\end{array}$ \\
\hline Log years of schooling (1960) & $\begin{array}{c}0.0060^{b} \\
(0.0025)\end{array}$ & $\begin{array}{c}0.0076^{\mathrm{a}} \\
(0.0024)\end{array}$ & $\begin{array}{l}0.0063^{b} \\
(0.0024)\end{array}$ & $\begin{array}{c}0.0060^{b} \\
(0.0023)\end{array}$ & $\begin{array}{l}0.0077^{b} \\
(0.0032)\end{array}$ & $\begin{array}{l}0.0073^{b} \\
(0.0031)\end{array}$ & $\begin{array}{c}0.0073^{\mathrm{a}} \\
(0.0025)\end{array}$ & $\begin{array}{c}0.0080^{\mathrm{a}} \\
(0.0026)\end{array}$ \\
\hline Share of population living in temperate zone (1995) & $\begin{array}{c}0.0175^{\mathrm{a}} \\
(0.0049)\end{array}$ & $\begin{array}{c}0.0132^{\mathrm{a}} \\
(0.0041)\end{array}$ & $\begin{array}{c}0.0179^{\mathrm{a}} \\
(0.0046)\end{array}$ & $\begin{array}{c}0.0104^{\mathrm{c}} \\
(0.0055)\end{array}$ & $\begin{array}{c}0.0242^{\mathrm{a}} \\
(0.0049)\end{array}$ & $\begin{array}{c}0.0231^{\mathrm{a}} \\
(0.0047)\end{array}$ & $\begin{array}{c}0.0175^{\mathrm{a}} \\
(0.0050)\end{array}$ & $\begin{array}{c}0.0184^{\mathrm{a}} \\
(0.0052)\end{array}$ \\
\hline Executive constraints (1960-2000) & $\begin{array}{l}0.0021^{b} \\
(0.0008)\end{array}$ & & & & & & & \\
\hline Expropriation risk (1982-1997) & & $\begin{array}{c}0.0040^{\mathrm{a}} \\
(0.0014)\end{array}$ & & & & & & \\
\hline Autocracy -- Alvarez (1960-1990) & & & $\begin{array}{c}-0.0060^{\mathrm{c}} \\
(0.0032)\end{array}$ & & & & & \\
\hline Government effectiveness (1998-2000) & & & & $\begin{array}{c}0.0075^{\mathrm{a}} \\
(0.0024)\end{array}$ & & & & \\
\hline Judicial independence (1995) & & & & & $\begin{array}{l}-0.0041 \\
(0.0057)\end{array}$ & & & \\
\hline Constitutional review (1995) & & & & & & $\begin{array}{c}0.0047 \\
(0.0064)\end{array}$ & & \\
\hline Plurality (1975-2000) & & & & & & & $\begin{array}{c}0.0010 \\
(0.0027)\end{array}$ & \\
\hline Proportional representation (1975-2000) & & & & & & & & $\begin{array}{c}0.0019 \\
(0.0031)\end{array}$ \\
\hline Observations & 71 & 69 & 71 & 71 & 54 & 54 & 71 & 70 \\
\hline $\mathrm{R}^{2}$ & 0.44 & 0.56 & 0.44 & 0.48 & 0.45 & 0.45 & 0.41 & 0.44 \\
\hline
\end{tabular}

$\mathrm{a}=$ significant at 1 percent; $\mathrm{b}=$ significant at 5 percent; $\mathrm{c}=$ significant at 10 percent. 


\section{Table 5}

\section{Economic growth, initial constraints on the executive and initial human capital}

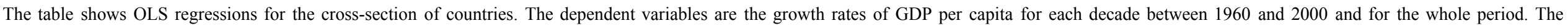
specifications include a constant but we do not report the estimates in the table. Robust standard errors are shown in parentheses. All variables are defined in Appendix 1.

\begin{tabular}{|c|c|c|c|c|c|}
\hline & \multicolumn{5}{|c|}{ Panel A: Dependent variables are the growth rates of GDP per capita for each decade between 1960 and 2000 and for the whole period } \\
\hline & $1960-70$ & $1970-80$ & $1980-90$ & 1990-2000 & $1960-2000$ \\
\hline \multirow{2}{*}{$\begin{array}{l}\text { Share of population living in } \\
\text { temperate zone (1995) }\end{array}$} & $0.0290^{\mathrm{a}}$ & $0.0225^{\mathrm{a}}$ & $0.0294^{\mathrm{a}}$ & 0.0085 & $0.0253^{\mathrm{a}}$ \\
\hline & $(0.0076)$ & $(0.0070)$ & $(0.0084)$ & $(0.0073)$ & $(0.0039)$ \\
\hline \multirow[t]{2}{*}{ Log initial GDP per capita } & -0.0059 & -0.0032 & $-0.0079^{b}$ & 0.0021 & $-0.0079^{\mathrm{a}}$ \\
\hline & $(0.0045)$ & $(0.0043)$ & $(0.0036)$ & $(0.0037)$ & $(0.0025)$ \\
\hline \multirow[t]{2}{*}{ Initial executive constraints } & 0.0008 & -0.0004 & $0.0027^{\mathrm{b}}$ & 0.0006 & 0.0013 \\
\hline & $(0.0013)$ & $(0.0014)$ & $(0.0012)$ & $(0.0016)$ & $(0.0009)$ \\
\hline Observations & 77 & 99 & 102 & 95 & 72 \\
\hline \multirow[t]{3}{*}{$\mathrm{R}^{2}$} & $17 \%$ & $6 \%$ & $19 \%$ & $6 \%$ & $34 \%$ \\
\hline & Panel B: Depen & the growth & capita for & ween 1960 at & he whole period \\
\hline & $1960-70$ & $1970-80$ & $1980-90$ & $1990-2000$ & $1960-2000$ \\
\hline \multirow{2}{*}{$\begin{array}{l}\text { Share of population living in } \\
\text { temperate zone (1995) }\end{array}$} & $0.0136^{\mathrm{b}}$ & $0.0204^{\mathrm{a}}$ & $0.0220^{\mathrm{a}}$ & $0.0123^{\mathrm{c}}$ & $0.0175^{\mathrm{a}}$ \\
\hline & $(0.0066)$ & $(0.0068)$ & $(0.0082)$ & $(0.0073)$ & $(0.0049)$ \\
\hline Log initial GDP per capita & $(0.0040)$ & $(0.0044)$ & $(0.0048)$ & $(0.0048)$ & $(0.0034)$ \\
\hline \multirow[t]{2}{*}{ Log initial years of schooling } & $0.0075^{\mathrm{b}}$ & $0.0147^{\mathrm{a}}$ & $0.0114^{\mathrm{a}}$ & $0.0102^{c}$ & $0.0073^{\mathrm{a}}$ \\
\hline & $(0.0033)$ & $(0.0035)$ & $(0.0043)$ & $(0.0060)$ & $(0.0024)$ \\
\hline Observations & 79 & 86 & 90 & 82 & 71 \\
\hline \multirow[t]{3}{*}{$\mathrm{R}^{2}$} & $22 \%$ & $24 \%$ & $16 \%$ & $9 \%$ & $38 \%$ \\
\hline & Panel C: Depen & the growt & capita for & ween 1960 a & he whole period \\
\hline & $1960-70$ & $1970-80$ & $1980-90$ & $1990-2000$ & $1960-2000$ \\
\hline \multirow{2}{*}{$\begin{array}{l}\text { Share of population living in } \\
\text { temperate zone (1995) }\end{array}$} & $0.0270^{\mathrm{a}}$ & $0.0191^{\mathrm{a}}$ & $0.0218^{\mathrm{a}}$ & $0.0135^{\mathrm{c}}$ & $0.0255^{\mathrm{a}}$ \\
\hline & $(0.0085)$ & $(0.0070)$ & $(0.0082)$ & $(0.0077)$ & $(0.0048)$ \\
\hline \multirow[t]{2}{*}{ Log initial GDP per capita } & $-0.0141^{\mathrm{a}}$ & $-0.0130^{b}$ & $-0.0146^{\mathrm{a}}$ & -0.0073 & $-0.0189^{\mathrm{a}}$ \\
\hline & $(0.0048)$ & $(0.0057)$ & $(0.0045)$ & $(0.0055)$ & $(0.0034)$ \\
\hline \multirow[t]{2}{*}{ Initial executive constraints } & -0.0004 & -0.0017 & $0.0031^{\mathrm{b}}$ & 0.0014 & 0.0008 \\
\hline & $(0.0012)$ & $(0.0016)$ & $(0.0013)$ & $(0.0015)$ & $(0.0008)$ \\
\hline Observations & 61 & 80 & 86 & 81 & 57 \\
\hline $\mathrm{R}^{2}$ & $33 \%$ & $20 \%$ & $20 \%$ & $9 \%$ & $55 \%$ \\
\hline
\end{tabular}

a=significant at 1 percent; $b=$ significant at 5 percent; $c=$ significant at 10 percent. 
Table 6

\section{Long-term economic growth, initial executive constraints and initial human capital}

The table shows OLS regressions for the cross-section of countries. The dependent variables are the growth rates of GDP per capita for each period. The specifications include a constant but we do not report the estimates in the table. Robust standard errors are shown in parentheses. All variables are defined in Appendix 1.

\begin{tabular}{|c|c|c|c|}
\hline & \multicolumn{3}{|c|}{ Panel A: Dependent variables are the growth rates of GDP per capita for each period } \\
\hline & $1870-1950$ & $1890-1950$ & $1900-1950$ \\
\hline Log initial GDP per capita & $\begin{array}{c}0.0027 \\
(0.0022)\end{array}$ & $\begin{array}{c}0.0050^{\mathrm{b}} \\
(0.0022)\end{array}$ & $\begin{array}{c}-0.0019 \\
(0.0038)\end{array}$ \\
\hline Initial executive constraints & $\begin{array}{l}-0.0001 \\
(0.0005)\end{array}$ & $\begin{array}{c}0.0002 \\
(0.0004)\end{array}$ & $\begin{array}{c}0.0006 \\
(0.0006)\end{array}$ \\
\hline \multirow[t]{3}{*}{$\mathrm{R}^{2}$} & $\begin{array}{c}29 \\
0.06\end{array}$ & $\begin{array}{c}27 \\
0.26\end{array}$ & $\begin{array}{c}31 \\
0.02\end{array}$ \\
\hline & Panel B: Depena & growth rate & for each period \\
\hline & $1870-1950$ & $1890-1950$ & $1900-1950$ \\
\hline \multirow[t]{2}{*}{ Log initial GDP per capita } & $-0.0076^{\mathrm{a}}$ & -0.0028 & -0.0011 \\
\hline & $(0.0013)$ & $(0.0025)$ & $(0.0037)$ \\
\hline \multirow[t]{2}{*}{ Initial executive constraints } & -0.0001 & -0.0002 & 0.0002 \\
\hline & $(0.0002)$ & $(0.0005)$ & $(0.0006)$ \\
\hline \multirow[t]{2}{*}{ Primary school enrollment 1870} & $0.0206^{\mathrm{a}}$ & & \\
\hline & $(0.0030)$ & & \\
\hline \multirow[t]{2}{*}{ Primary school enrollment 1890} & & $0.0127^{\mathrm{b}}$ & \\
\hline & & $(0.0056)$ & \\
\hline \multirow[t]{2}{*}{ Primary school enrollment 1900} & & & 0.0067 \\
\hline & & & $(0.0066)$ \\
\hline Observations & 16 & 23 & 27 \\
\hline $\mathrm{R}^{2}$ & 0.73 & 0.21 & 0.08 \\
\hline
\end{tabular}

$\mathrm{a}=$ significant at 1 percent; $\mathrm{b}=$ significant at 5 percent; $\mathrm{c}=$ significant at 10 percent. 


\section{Table 7}

\section{Political regimes and human capital}

Distribution of countries by years of schooling in 1960 and political regimes. The classification of political regimes is based on the average democracy score for 19602000 from the Polity IV database. We divide the sample of countries into those with low human capital (years of schooling below the sample's median value of 2.6785), intermediate human capital (years of schooling between 2.6785 and 5.0115), and high human capital (years schooling above the sample's $75^{\text {th }}$ percentile value of 5.0115 years). The table shows the number of countries that fall within each group. All variables are defined in Appendix 1.

\begin{tabular}{|c|c|c|c|c|c|}
\hline Years of schooling (1960) & Democracy $=10$ & $10>$ Democracy $>7$ & $7 \geq$ Democracy $>2$ & Democracy $\leq 2$ & All countries \\
\hline Low (yrs. schooling < 2.6785) & 0 & 6 & 8 & 28 & 42 \\
\hline Intermediate $(2.6785 \leq$ yrs. schooling $\leq 5.0115)$ & 2 & 5 & 14 & 3 & 24 \\
\hline High (yrs. schooling >5.0115) & 17 & 3 & 3 & 0 & 23 \\
\hline Total & 19 & 14 & 25 & 31 & 89 \\
\hline
\end{tabular}

Note: The two stable democracies with intermediate schooling levels are Italy and Costa Rica. The three authoritarian countries with intermediate schooling levels are Singapore, Taiwan and Paraguay. 


\section{Table 8}

\section{Growth rates and political regimes}

The table is based on the sample of countries described in Table 7. The table shows the number of observations for each group of countries, the average within-country 10-year GDP per capita growth rates and the mean standard deviation of the 10-year GDP per capita growth rates across countries. The democracy score is computed at the beginning of each decade using the preceding ten years of data. We measure growth at the beginnig of each decade using the subsequent ten years. All variables are defined in Appendix 1.

\begin{tabular}{|c|c|c|c|c|c|}
\hline Years of schooling (1960) & Democracy $=10$ & $10>$ Democracy $>7$ & $7 \geq$ Democracy $>2$ & Democracy $\leq 2$ & All countries \\
\hline & \multicolumn{5}{|c|}{ Panel A: Number of observations } \\
\hline Low (yrs. schooling < 2.6785) & 6 & 17 & 22 & 87 & 132 \\
\hline Intermediate $(2.6785 \leq$ yrs. schooling $\leq 5.0115)$ & 9 & 21 & 26 & 35 & 91 \\
\hline High (yrs. schooling $>5.0115)$ & 67 & 10 & 3 & 7 & 87 \\
\hline \multirow[t]{2}{*}{ Total } & 82 & 48 & 51 & 129 & 310 \\
\hline & \multicolumn{5}{|c|}{ Panel B: Average within-country 10-year growth rate } \\
\hline Low (yrs. schooling < 2.6785) & 0.0036 & 0.0292 & 0.0185 & 0.0076 & 0.0120 \\
\hline Intermediate $(2.6785 \leq$ yrs. schooling $\leq 5.0115)$ & 0.0225 & 0.0224 & 0.0271 & 0.0273 & 0.0256 \\
\hline High (yrs. schooling $>5.0115)$ & 0.0257 & 0.0212 & 0.0235 & 0.0204 & 0.0247 \\
\hline \multirow[t]{2}{*}{ Total } & 0.0238 & 0.0246 & 0.0232 & 0.0136 & 0.0196 \\
\hline & \multicolumn{5}{|c|}{ Panel C: Mean standard deviation of the 10-year growth rates across countries } \\
\hline Low (yrs. schooling < 2.6785) & 0.0168 & 0.0298 & 0.0224 & 0.0303 & 0.0294 \\
\hline Intermediate $(2.6785 \leq$ yrs. schooling $\leq 5.0115)$ & 0.0161 & 0.0197 & 0.0206 & 0.0317 & 0.0247 \\
\hline High (yrs. schooling > 5.0115) & 0.0137 & 0.0122 & 0.0078 & 0.0250 & 0.0144 \\
\hline Total & 0.0151 & 0.0225 & 0.0210 & 0.0315 & 0.0254 \\
\hline
\end{tabular}




\section{Table 9 \\ Percentage of years spent under different political regimes}

The table presents the mean percentage of years that countries spent under autocratic or democratic regimes from 1960 to 1990. The sample only includes countries with years of schooling in 1960 below 5.0115 (low and intermediate levels of human capital). The classification into autocracy and democracy comes from the data in Alvarez et al. (2000). For each type of political regime, we split the sample into four groups depending on the length of the tenure of the leader. All variables are defined in Appendix 1.

\begin{tabular}{|c|c|c|}
\hline & $\begin{array}{c}\text { Low } \\
\text { (yrs. schooling }<2.6785)\end{array}$ & $\begin{array}{c}\text { Intermediate } \\
(2.6785 \leq \text { yrs. } \text { schooling } \leq 5.0115)\end{array}$ \\
\hline & Percentage of years & Percentage of years \\
\hline \multicolumn{3}{|c|}{ Length of leader $<2$ years } \\
\hline Autocratic regime & $1.62 \%$ & $1.90 \%$ \\
\hline Democratic regime & $0.52 \%$ & $2.45 \%$ \\
\hline \multicolumn{3}{|c|}{ Length of leader $\geq 2$ years but $<5$ years } \\
\hline Autocratic regime & $10.93 \%$ & $10.28 \%$ \\
\hline Democratic regime & $5.25 \%$ & $18.30 \%$ \\
\hline \multicolumn{3}{|c|}{ Length of leader $\geq 5$ years but $<10$ years } \\
\hline Autocratic regime & $16.32 \%$ & $11.83 \%$ \\
\hline Democratic regime & $7.32 \%$ & $14.32 \%$ \\
\hline \multicolumn{3}{|c|}{ Length of leader $\geq 10$ years } \\
\hline Autocratic regime & $49.80 \%$ & $32.33 \%$ \\
\hline Democratic regime & $6.15 \%$ & $8.58 \%$ \\
\hline
\end{tabular}




\section{Table 10}

The table shows OLS regressions for the cross-section of countries. The specifications include a constant but we do not report the estimates in the table. Robust standard errors are shown in parentheses. All definitions are in Appendix 1.

\begin{tabular}{|c|c|c|c|c|}
\hline & \multicolumn{4}{|c|}{ Dependent variables: } \\
\hline & $\begin{array}{c}\text { Executive constraints } \\
(1960-2000)\end{array}$ & $\begin{array}{c}\text { Expropriation risk } \\
(1982-1997)\end{array}$ & $\begin{array}{c}\text { Autocracy -- Alvarez } \\
(1960-1990) \\
\end{array}$ & $\begin{array}{c}\text { Government effectiveness } \\
(1998-2000)\end{array}$ \\
\hline \multirow[t]{2}{*}{ Log settler mortality } & $-0.4351^{b}$ & $-0.3543^{b}$ & $0.0938^{\mathrm{c}}$ & $-0.2034^{\mathrm{b}}$ \\
\hline & $(0.1965)$ & $(0.1764)$ & $(0.0507)$ & $(0.0918)$ \\
\hline \multirow[t]{2}{*}{ Population at risk of malaria (1994) } & $-1.5215^{\mathrm{a}}$ & $-0.9679^{b}$ & $0.4397^{\mathrm{a}}$ & $-0.7745^{\mathrm{a}}$ \\
\hline & $(0.5504)$ & $(0.3731)$ & $(0.1597)$ & $(0.2133)$ \\
\hline Observations & 74 & 66 & 74 & 77 \\
\hline $\mathrm{R}^{2}$ & 0.36 & 0.32 & 0.29 & 0.43 \\
\hline
\end{tabular}

$\mathrm{a}=$ significant at 1 percent; $\mathrm{b}=$ significant at 5 percent; $\mathrm{c}=$ significant at 10 percent. 


\section{Table 11}

\section{Economic development, instrumental variable regressions}

The table shows instrumental variables regressions for the cross-section of countries. Panel A reports the second-stage estimates from instrumental variables regressions with first-stage estimates shown in Panel B. The dependent variable in both second-stage specifications is the log of GDP per capita in 2000. Panel B reports the first-stage estimates for two sets of instruments. The first specification instruments executive constraints and years of schooling using the log of settler mortality and French legal origin. The second specification instruments executive constraints and years of schooling using the log of population density in 1500 and French legal origin. The specifications in both stages include a constant but we do not report the estimates in the table. Robust standard errors are reported in parentheses. All variables are defined in Appendix 1.

Panel A: Second-stage regressions

Dependent variable is log GDP per capita in 2000

\section{(1)}

Years of schooling (1960-2000)

Executive constraints (1960-2000)

Share of population living in temperate zone

(1995)

Observations

$\mathrm{R}^{2}$ $0.7894^{\mathrm{a}}$

$(0.2753)$

$-0.3432$

$(0.2577)$

$-1.6969$

(1.2053)

47

0.31
(2)

$0.4836^{\mathrm{b}}$

$(0.1875)$

$-0.2965$

(0.2410)

$-0.0863$

$(0.7714)$

55

0.5

\begin{tabular}{c} 
Panel B: First-stage regressions \\
\cline { 2 - 3 }
\end{tabular}

\begin{tabular}{lcc|cc} 
& $\begin{array}{c}\text { Executive constraints } \\
(1960-2000)\end{array}$ & $\begin{array}{c}\text { Years of schooling } \\
(1960-2000)\end{array}$ & $\begin{array}{c}\text { Executive constraints } \\
(1960-2000)\end{array}$ & $\begin{array}{c}\text { Years of schooling } \\
(1960-2000)\end{array}$ \\
\hline Share of population living in temperate zone & -0.1195 & $3.4975^{\mathrm{a}}$ & -0.0353 & $2.8397^{\mathrm{a}}$ \\
$(1995)$ & $(0.7202)$ & $(0.8044)$ & $(0.8359)$ & $(0.8933)$
\end{tabular}

Log settler mortality

$-0.8212^{\mathrm{a}}$

$-1.0183^{\mathrm{a}}$

(0.2053)

(0.2293)

Log population density in 1500

$\begin{array}{ll}-0.3737^{\mathrm{b}} & -0.6140^{\mathrm{a}} \\ (0.1582) & (0.1691)\end{array}$

French legal origin

$-1.4124^{\mathrm{a}} \quad-0.3770$

$-1.1988^{\mathrm{b}}$

$-0.5329$

$(0.4258)$

(0.4757)

$(0.4538)$

$(0.4850)$

Observations 47

$\begin{array}{ll}\mathrm{R}^{2} & 0.53\end{array}$

$47 \quad 47$

55

55

F-Test for excluded instruments

0.70

0.25

0.55

Correlation of predicted values of executive

constraints and years of schooling

17.23

0.8182

4.70

0.8163

$\mathrm{a}=$ significant at the 1 percent; $\mathrm{b}=$ significant at the 5 percent; $\mathrm{c}=$ significant at 10 percent. 


\section{Table 12}

The table shows OLS regressions with country fixed effects for the cross-section of countries. The specifications include a constant and country fixed effects but we do not report the estimates in the table. Errors are clustered at the country level and reported in parentheses. All definitions are in Appendix 1.

\begin{tabular}{|c|c|c|c|c|}
\hline \multirow[b]{2}{*}{ Years of schooling $(\mathrm{t})$} & \multicolumn{4}{|c|}{ Panel A: Dependent variable is the 5-year change in years of schooling $(t+5, t)$} \\
\hline & $\begin{array}{l}-0.0721^{\mathrm{a}} \\
(0.0237)\end{array}$ & $\begin{array}{l}-0.0460 \\
(0.0339)\end{array}$ & $\begin{array}{l}-0.0707^{\mathrm{a}} \\
(0.0250)\end{array}$ & $\begin{array}{l}-0.0691^{\mathrm{a}} \\
(0.0239)\end{array}$ \\
\hline Log GDP per capita (t) & $\begin{array}{l}0.2839^{\mathrm{a}} \\
(0.0790)\end{array}$ & $\begin{array}{l}0.3978^{\mathrm{a}} \\
(0.1055)\end{array}$ & $\begin{array}{l}0.2809^{\mathrm{a}} \\
(0.0797)\end{array}$ & $\begin{array}{l}0.2825^{\mathrm{a}} \\
(0.0793)\end{array}$ \\
\hline Executive constraints $(\mathrm{t})$ & $\begin{array}{l}-0.0099 \\
(0.0118)\end{array}$ & & & \\
\hline Autocracy -- Polity IV (t) & & $\begin{array}{c}0.0373 \\
(0.0391)\end{array}$ & & \\
\hline Autocracy -- Alvarez (t) & & & $\begin{array}{c}0.0065 \\
(0.0080)\end{array}$ & \\
\hline Democracy $(\mathrm{t})$ & & & & $\begin{array}{l}-0.0094 \\
(0.0074)\end{array}$ \\
\hline Observations & 514 & 420 & 514 & 514 \\
\hline \multirow[t]{3}{*}{$\mathrm{R}^{2}$} & 0.24 & 0.26 & 0.24 & 0.24 \\
\hline & \multicolumn{4}{|c|}{ Panel B: Dependent variables are the 5-year changes in political institutions $(t+5, t)$} \\
\hline & $\begin{array}{c}\text { Change executive } \\
\text { constraints }\end{array}$ & $\begin{array}{c}\text { Change autocracy -- } \\
\text { Polity IV }\end{array}$ & $\begin{array}{c}\text { Change autocracy -- } \\
\text { Alvarez }\end{array}$ & $\begin{array}{c}\text { Change } \\
\text { democracy }\end{array}$ \\
\hline Years of schooling $(\mathrm{t})$ & $\begin{array}{l}0.4975^{\mathrm{a}} \\
(0.1191)\end{array}$ & $\begin{array}{l}-0.9092^{a} \\
(0.1790)\end{array}$ & $\begin{array}{c}-0.0958 \\
(0.0707)\end{array}$ & $\begin{array}{l}0.7004^{\mathrm{a}} \\
(0.1804)\end{array}$ \\
\hline Log GDP per capita (t) & $\begin{array}{c}0.0382 \\
(0.4035)\end{array}$ & $\begin{array}{c}0.5075 \\
(0.6295)\end{array}$ & $\begin{array}{l}-0.2675 \\
(0.2022)\end{array}$ & $\begin{array}{c}0.2918 \\
(0.6055)\end{array}$ \\
\hline Executive constraints $(\mathrm{t})$ & $\begin{array}{l}-0.5724^{\mathrm{a}} \\
(0.0716)\end{array}$ & & & \\
\hline Autocracy -- Polity IV (t) & & $\begin{array}{l}-0.5471^{\mathrm{a}} \\
(0.0680)\end{array}$ & & \\
\hline Autocracy -- Alvarez (t) & & & $\begin{array}{l}-0.8642^{a} \\
(0.1032)\end{array}$ & \\
\hline Democracy $(\mathrm{t})$ & & & & $\begin{array}{l}-0.5145^{\mathrm{a}} \\
(0.0650)\end{array}$ \\
\hline Observations & 499 & 499 & 349 & 499 \\
\hline $\mathrm{R}^{2}$ & 0.33 & 0.32 & 0.47 & 0.30 \\
\hline
\end{tabular}

$\mathrm{a}=$ significant at 1 percent; $\mathrm{b}=$ significant at 5 percent; $\mathrm{c}=$ significant at 10 percent. 
Figure 1: Executive Constraints 1948-2001

North versus South Korea

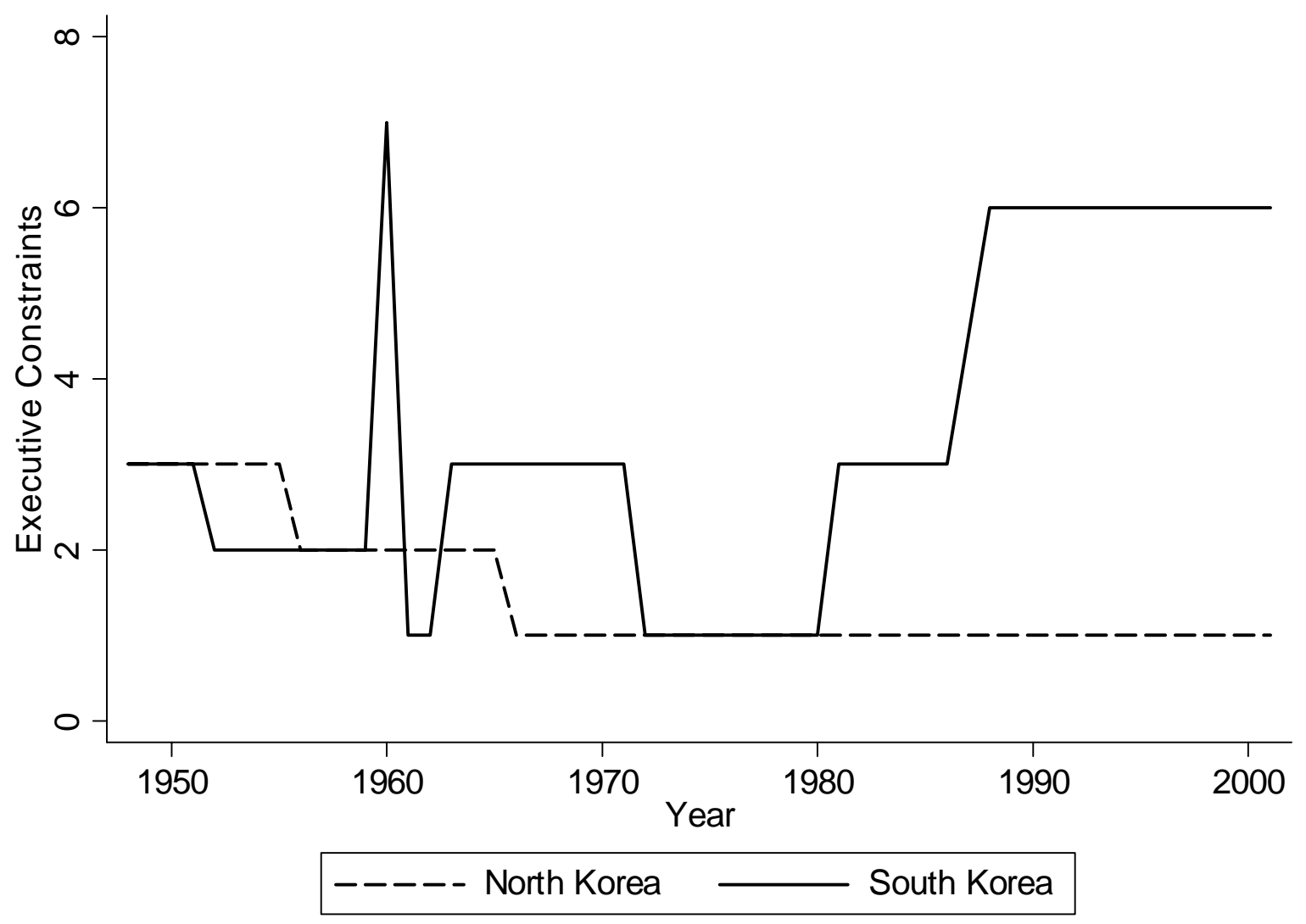


Figure 2

Years of schooling (1960) and Log settler mortality

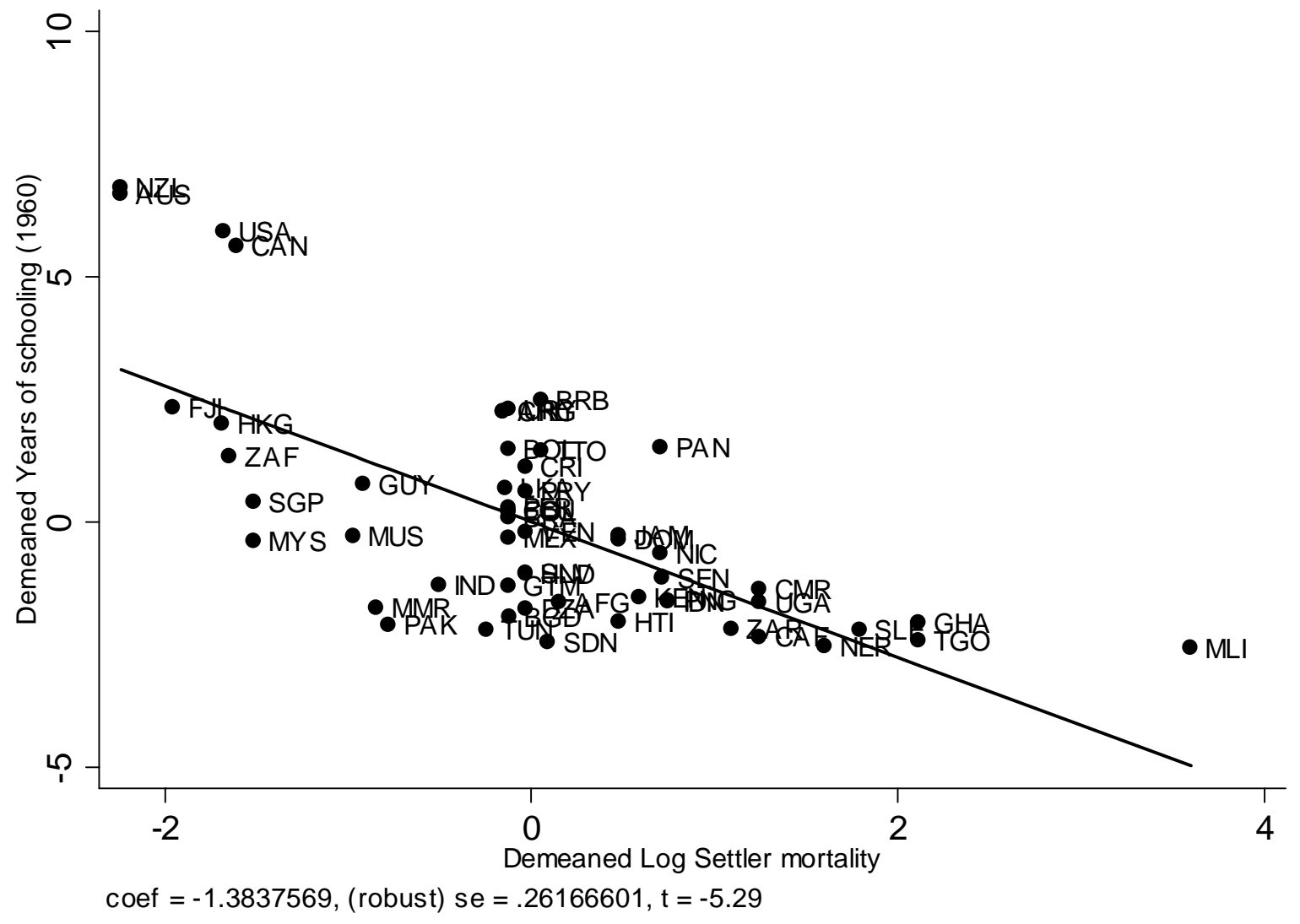


Figure 3

Years of schooling (1960) and Log population density in 1500

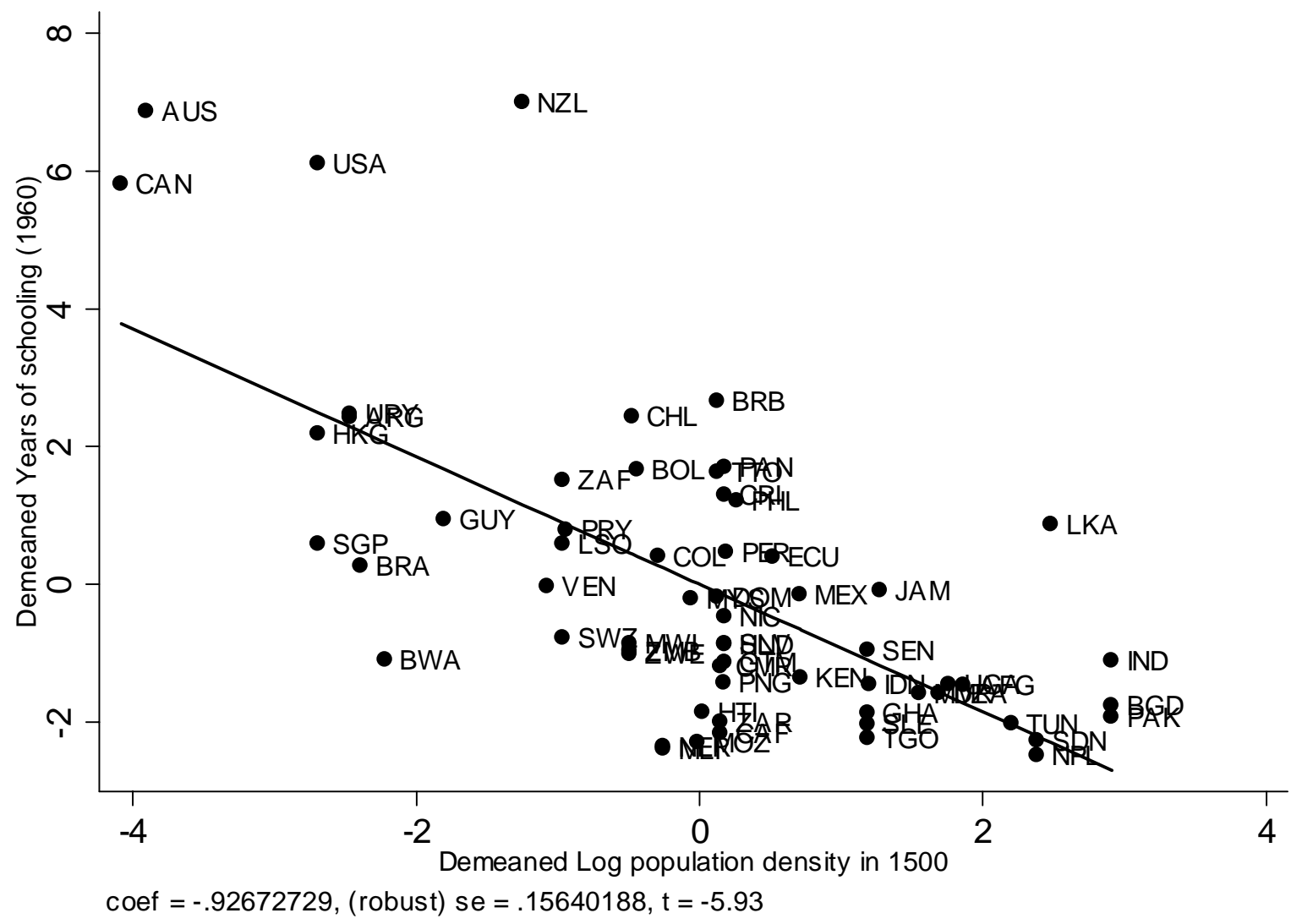


Figure 4

Years of schooling (2000) and Log settler mortality

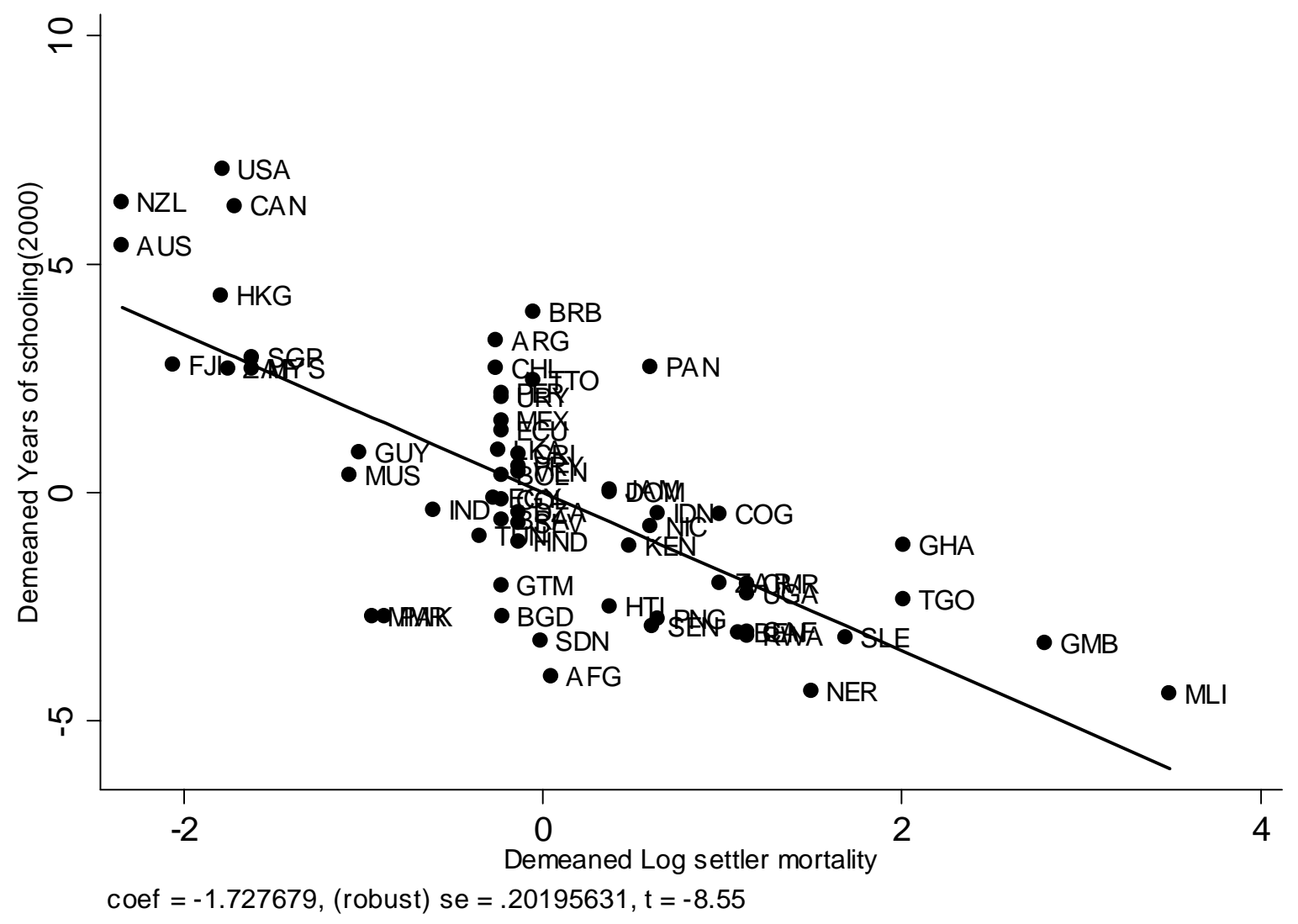


Figure 5

Years of schooling (2000) and Log population density in 1500

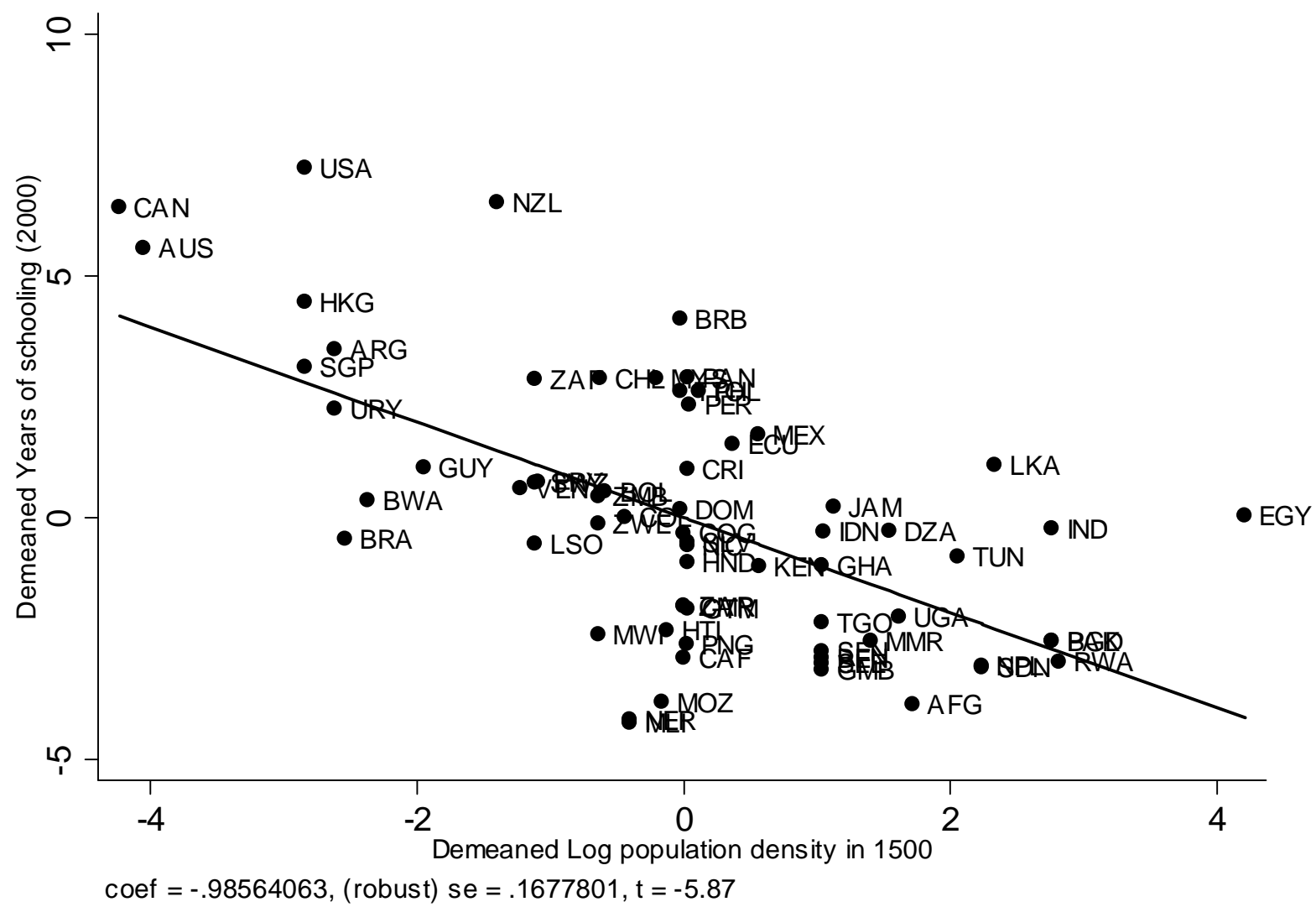




\section{Figure 6}

Log GDP per capita (2000) and Primary school enrollment (1900)

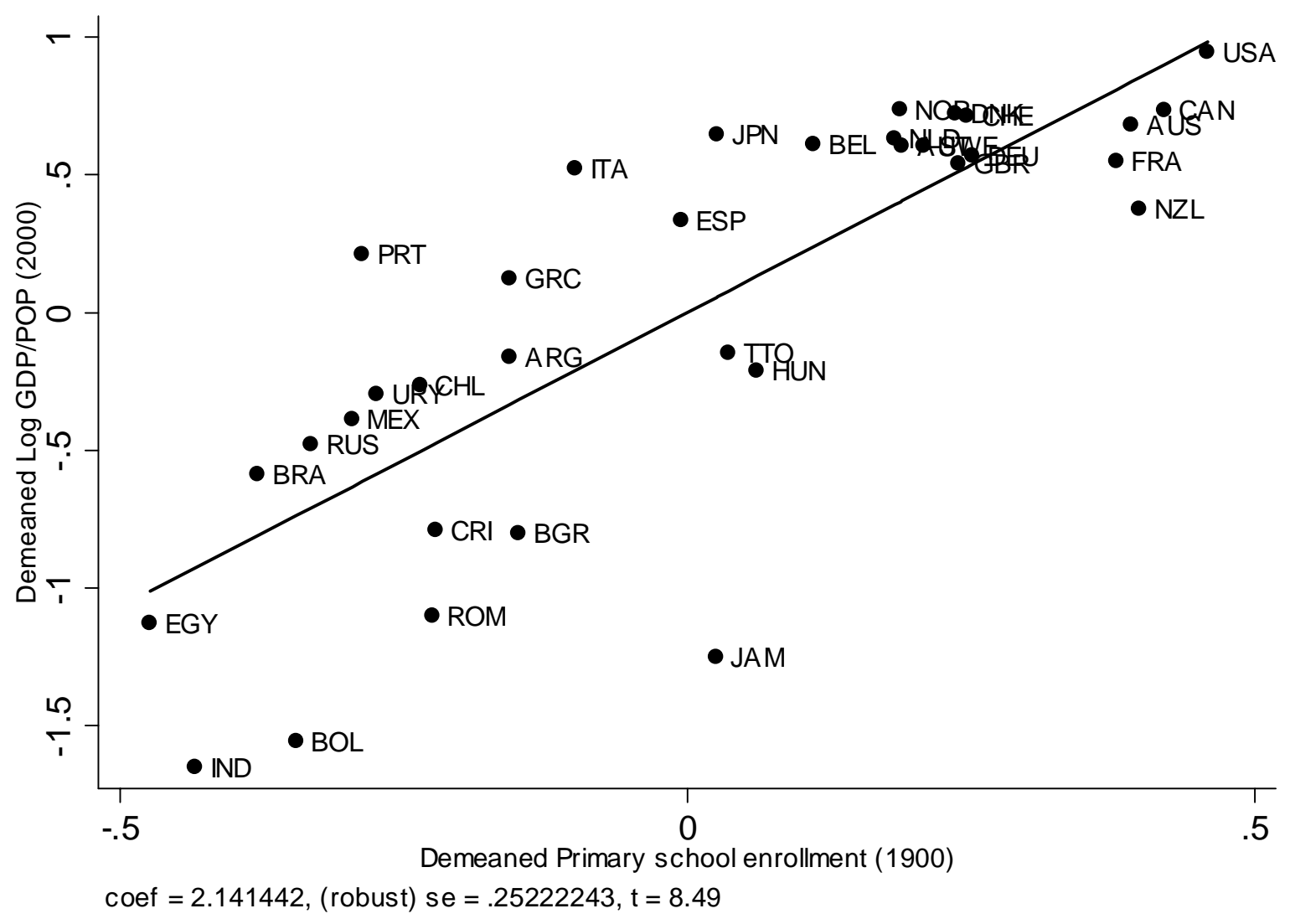


Figure 7

Primary school enrollment (1900) and Log settler mortality

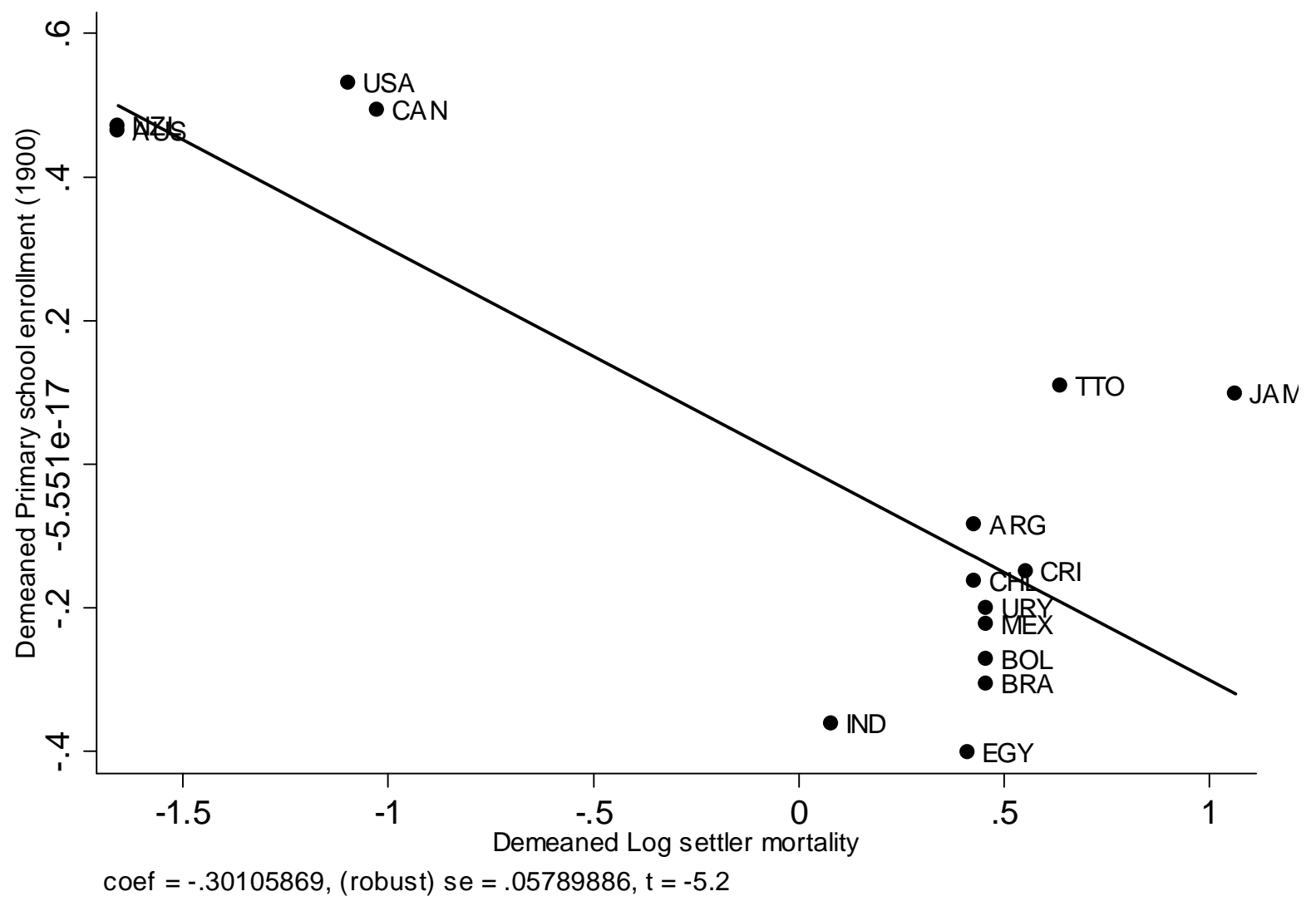


Figure 8

Primary school enrollment (1900) and Log population density in 1500

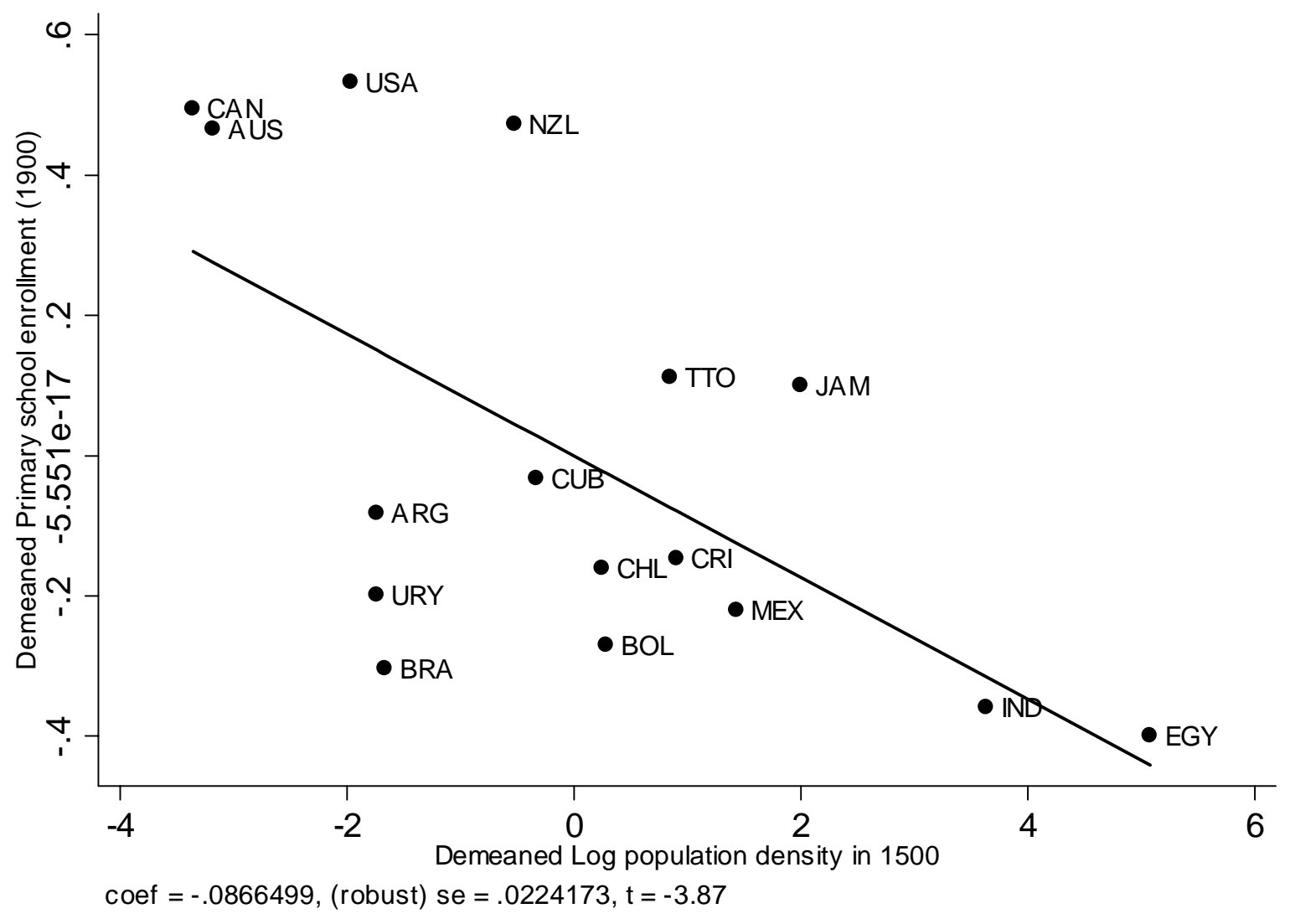




\begin{tabular}{|c|c|}
\hline Variable & Definition \\
\hline & Measures of institutions \\
\hline Executive constraints & $\begin{array}{l}\text { A measure of the extent of institutionalized constraints on the decision making powers of chief executives. The variable takes } \\
\text { seven different values: (1) Unlimited authority (there are no regular limitations on the executive's actions, as distinct from } \\
\text { irregular limitations such as the threat or actuality of coups and assassinations); (2) Intermediate category; (3) Slight to moderate } \\
\text { limitation on executive authority (there are some real but limited restraints on the executive); (4) Intermediate category; (5) } \\
\text { Substantial limitations on executive authority (the executive has more effective authority than any accountability group but is } \\
\text { subject to substantial constraints by them); (6) Intermediate category; (7) Executive parity or subordination (accountability groups } \\
\text { have effective authority equal to or greater than the executive in most areas of activity). This variable ranges from one to seven } \\
\text { where higher values equal a greater extent of institutionalized constraints on the power of chief executives. This variable is } \\
\text { calculated as the average from } 1960 \text { through } 2000 \text {, or for specific years as needed in the tables. Source: Jaggers and Marshall (20) }\end{array}$ \\
\hline
\end{tabular}

Democracy

Autocracy -- Polity IV

Expropriation risk

Autocracy -- Alvarez

Government effectiveness

Judicial independence

Constitutional review

Plurality

Proportional representation
A measure of the degree of democracy in a given country based on: (1) the competitiveness of political participation; (2) the openness and competitiveness of executive recruitment; and (3) the constraints on the chief executive. The variable ranges from zero to ten, where higher values equal a higher degree of institutionalized democracy. This variable is calculated as the average from 1960 through 2000, or for specific years as needed in the tables. Source: Jaggers and Marshall (2000).

A measure of the degree of autocracy in a given country based on: (1) the competitiveness of political participation; (2) the regulation of political participation; (3) the openness and competitiveness of executive recruitment; and (4) constraints on the chief executive. This variable ranges from zero to ten where higher values equal a higher degree of institutionalized autocracy. This variable is calculated as the average from 1960 through 2000, or for specific years as needed in the tables. Source: Jaggers and Marshall (2000).

Risk of "outright confiscation and forced nationalization" of property. This variable ranges from zero to ten where higher values are equals a lower probability of expropriation. This variable is calculated as the average from 1982 through 1997 , or for specific years as needed in the tables. Source: International Country Risk Guide at http:/www.countrydata.com/datasets/.

This variable classifies regimes based on their degree of autocracy. Democracies are coded as 0 , bureaucracies (dictatorships with a legislature) are coded as 1 and autocracies (dictatorship without a legislature) are coded as 2 . Transition years are coded as the regime that emerges afterwards. This variable ranges from zero to two where higher values equal a higher degree of autocracy. This variable is measured as the average from 1960 through 1990; or for specific years as needed in the tables. Source: Alvarez et al. (2000).

This variable measures the quality of public service provision, the quality of the bureaucracy, the competence of civil servants, the independence of the civil service from political pressures, and the credibility of the government's commitment to policies. The main focus of this index is on "inputs" required for the government to be able to produce and implement good policies and deliver public goods. This variable ranges from -2.5 to 2.5 where higher values equal higher government effectiveness. This variable is measured as the average from 1998 through 2000. Source: Kaufman et al. (2003).

Judicial independence is computed as the sum of three variables. The first measures the tenure of Supreme Court judges (highest court in any country) and takes a value of 2 - if tenure is lifelong, 1 - if tenure is more than six years but not lifelong, and 0 - if tenure is less than six years. The second measures the tenure of the highest ranked judges ruling on administrative cases and takes a value of 2 - if tenure is lifelong, 1 - if tenure is more than six years but not lifelong, 0 - if tenure is less than six years. The third measures the existence of case law and takes a value of 1 if judicial decisions in a given country are a source of law, and 0 otherwise. The variable is normalized from zero to one where higher values equal a higher degree of judicial independence. This variable is measured as of 1995. Source: La Porta et al. (2004).

Constitutional review is computed as the sum of two variables. The first variable measures the extent to which judges (either Supreme Court or constitutional court) have the power to review the constitutionality of laws in a given country. The variable takes three values: 2 - if there is full review of constitutionality of laws, 1 - if there is limited review of constitutionality of laws, 0 . if there is no review of constitutionality of laws. The second variable measures (on a scale from 1 to 4 ) how hard it is to change the constitution in a given country. One point each is given if the approval of the majority of the legislature, the chief of state and a referendum is necessary in order to change the constitution. An additional point is given for each of the following: if a supermajority in the legislature (more than $66 \%$ of votes) is needed, if both houses of the legislature have to approve, if the legislature has to approve the amendment in two consecutive legislative terms or if the approval of a majority

of state legislature is required. This variable is normalized from zero to one where higher values equal a higher degree of constitutional review by the courts. This variable is measured as of 1995. Source: La Porta et al. (2004).

This variable is equal to one for each year in which legislators were elected using a winner-take-all / first past the post rule; it equals zero otherwise. This variable is measured as the average from 1975 through 2000. Source: Beck et al. (2001).

This variable is equal to one for each year in which candidates were elected using a proportional representation system; equals zero otherwise. Proportional representation means that candidates are elected based on the percentage of votes received by their party. This variable is measured as the average from 1975 through 2000. Source: Beck et al. (2001). 
Other variables

Share of population living in temperate zone

Log settler mortality

Population density in 1500

Population at risk of malaria

Malaria ecology

Years of schooling

Primary school enrollment

Legal origin

GDP per capita
Percentage of a country's population in Koeppen-Geiger temperate zone in 1995. Source: Center for International Development, Geography Data Sets. Found online at: http://www2.cid.harvard.edu/ciddata/geographydata.htm\#General\%20measures\%20of\%20geography.

Log of the mortality rate faced by European settlers at the time of colonization. Source: Acemoglu, et al. (2001).

Total population divided by total arable land in 1500 A.D. Source: McEvedy and Jones (1978) as cited in Acemoglu, et al. (2002).

Percentage of the population at risk of malaria transmission in 1994. Source: World Health Organization (1997).

Malaria Ecology, pop-weighted, Sept 2003 version. This variable provides an instrument for malaria risk that controls for the fact that causation may run not only from malaria to income but also from income to malaria. The basic formula for ME includes temperature, species abundance, and vector type (the type of mosquito). The underlying index is measured on a highly disaggregated sub-national level, and then is averaged for the entire country. Because ME is built upon climatological and vector conditions on a country-by-country basis, it is exogenous to public health interventions and economic conditions. Source: Kiszewski et al. (2004).

Years of schooling of the total population aged over 25. This variable is constructed as the average from 1960 through 2000 ; or for specific years as needed in the tables. Source: Barro, Robert J. and Jong-Wha Lee, International Data on Educational Attainment: Updates and Implications. Source: Barro and Lee (2000) Data posted on http://www.cid.harvard.edu/ciddata/ciddata.html

This variable measures primary school enrollment as a percentage of children aged 5 through 14 . Measured in 1870,1890 , and 1900. Source: Lindert (2001).

Identifies the legal origin of the company law or commercial code of each country (English, French, Socialist, German, Scandinavian). Source: La Porta et al. (1999).

Gross domestic product over population. Source: Aten et al. (2002). Data available on-line at: http://pwt.econ.upenn.edu/ (this paper uses data from the 04-06-2003 version). GDP per capita for the 1870-1950 period comes from Maddison (2003). 